\title{
CONCESSÕES FLORESTAIS E GERAÇÃO DE ENERGIA POR BIOMASSA DE RESÍDUOS MADEIREIROS
}

\section{FOREST CONCESSIONS AND POWER GENERATION BY TIMBER WASTE BIOMASS}

\author{
Flavia da Costa Limmer ${ }^{1}$
}

\section{Resumo}

Mesmo com a recente expansão do setor de petróleo e gás no Brasil o Poder Executivo Federal busca novas fontes energéticas. A atual Sociedade de Risco, modelo teórico proposto por Ulrich Beck, impõe a autonomia energética pautada em energias renováveis. O padrão baseado em combustíveis fósseis possui fragilidades, tanto ambientais quanto econômicas, uma vez que é extremamente poluente e está sujeito a flutuações do mercado internacional.

O sistema normativo brasileiro reconhece a importância da economia para preservação ambiental e o desenvolvimento da sociedade. A própria Constituição da República de 1988 aponta para a necessidade de compatibilizar preservação ambiental com desenvolvimento econômico. De fato, embora a ordem econômica no Brasil seja norteada pelos princípios da livre concorrência e da livre iniciativa, a atuação do empresariado deve ser compatibilizada com os interesses ambientais e sociais, tal como transparece no artigo 170 da Constituição da República.

Tal situação se agrava na modernização reflexiva, onde as formas tradicionais de geração de energia passam a ter seu papel e importância questionados. A Sociedade de Risco se traduz em uma pressão constante no direito e na economia. O empresariado também é chamado para colaborar com a solução da crise ambiental. A responsabilidade socioambiental da empresa passa a ser exigida como uma contrapartida pelos lucros obtidos, e esta deverá buscar contribuir com a ampliação das energias renováveis.

Os princípios constitucionais ambientais, tais como o da cooperação, o do desenvolvimento sustentável e o do poluidor-pagador são vetores para a troca de padrão energético, com a adoção da geração de energia através da biomassa de resíduos. Este novo modelo é especialmente atrativo em razão do endurecimento legislativo sobre a questão do lixo, através da promulgação da Lei de Gestão de Resíduos Sólidos - Lei n 10.305/2010.

O presente trabalho visa analisar a possibilidade de exigência de projetos de geração de energia proveniente de biomassa de resíduos florestais nas concessões florestais. Procura-se mostrar que a biomassa de resíduos é uma alternativa viável, que pode gerar renda para o empresariado, diminuindo ou mesmo zerando a demanda energética do processo produtivo. Na mesma linha, os resíduos dos produtos madeireiros podem ser doados às populações tradicionais, solucionando a demanda energética das áreas com baixos índices de eletrificação.

No contexto das licitações verdes, novo padrão a ser observado pelo Poder Público, um dos instrumentos que o Ministério do Meio Ambiente e o Serviço Florestal Brasileiro poderiam utilizar para impor a destinação dos resíduos florestais para a produção de energia oriunda de biomassa nas concessões florestais seria a inclusão desta regra em editais das próximas ofertas de concessão florestal, como se procura aprofundar no presente trabalho.

\footnotetext{
${ }^{1}$ Doutora em Direito pela Universidade do Estado do Rio de Janeiro - UERJ. Mestre em Direito pela Pontifícia Universidade Católica do Rio de Janeiro. Atualmente realiza estágio pós doutoral na UERJ, sobre o tema Regulação Ambiental do Gás de Xisto e da Técnica de Fraturamento Hidráulico. Professora Adjunta na Pontifícia Universidade Católica do Rio de Janeiro. Leciona ainda nos cursos de especialização da Escola da Magistratura do Rio de Janeiro (EMERJ), no CEPED - UERJ, no IBMEC e na FGV. - email: flaviaclimmer@gmail.com
} 
Palavras-chave: Biomassa. Concessões Florestais. Desenvolvimento Sustentável.

\section{Abstract}

Even with the recent expansion of the oil and gas sector in Brazil the Federal Executive Branch seeks new energy sources. The current Risk Society, theoretical model proposed by Ulrich Beck, imposes energy autonomy guided by renewable energy. The standard based on fossil fuels has weaknesses, both environmental and economic, since it is very polluting and is subjected to international market fluctuations.

The Brazilian legal system recognizes the importance of savings for environmental preservation and the development of society. The 1988 Republican Constitution points to the need of reconciling environmental conservation with economic development. In fact, although the economic order in Brazil is guided by the principles of free competition and free enterprise, the business community's role must be rendered compatible with the environmental and social interests, as is reflected in Article 170 of the Constitution.

This situation gets worse in reflexive modernization, where traditional forms of power generation now have its role and importance questioned. The Risk Society translates into a constant pressure on the right and the economy. The business community is also called to collaborate with the solution of the environmental crisis. The environmental responsibility of the company will be required as a consideration for the profits made, and it should seek to contribute to the expansion of renewable energies.

Environmental constitutional principles, such as the cooperation, sustainable development and the polluter-pays are vectors for the exchange of energy pattern, with the adoption of energy generation from biomass residues. This new model is especially attractive because of legislative hardening on the issue of waste, through the enactment of the Solid Waste Management Act - Law No. 10,305 / 2010. This study aims to examine the possibility of demand for power generation projects from biomass of forest residues in forest concessions. It will be shown that biomass waste is a viable alternative that can generate income for the business, reducing or even resetting the energy demand of the production process. Similarly, the waste wood products can be donated to traditional populations, solving the energy demand of the areas with low rates of electrification.

In the context of green bidding, new standard to be observed by the Government, one of the instruments that the Ministry of Environment and the Forest Service could use to enforce the allocation of forest residues for energy production from biomass in forest concessions would be the inclusion of this rule in notices of upcoming offers from forest concession, as if looking further in this study.

Keywords: Biomass, forest concessions, sustainable Development.

\section{INTRODUÇÃO}

Mesmo com a recente expansão do setor de petróleo e gás no Brasil o Poder Executivo Federal busca novas fontes energéticas. A atual Sociedade de Risco, modelo teórico proposto por Ulrich Beck, impõe a autonomia energética pautada em energias renováveis. O padrão baseado em 
combustíveis fósseis possui fragilidades, tanto ambientais quanto econômicas, uma vez que é extremamente poluente e está sujeito a flutuações do mercado internacional.

O sistema normativo brasileiro reconhece a importância da economia para preservação ambiental e o desenvolvimento da sociedade. A própria Constituição da República de 1988 aponta para a necessidade de compatibilizar preservação ambiental com desenvolvimento econômico. De fato, embora a ordem econômica no Brasil seja norteada pelos princípios da livre concorrência e da livre iniciativa, a atuação do empresariado deve ser compatibilizada com os interesses ambientais e sociais, tal como transparece no artigo 170 da Constituição da República. Para Cass Sunstein os riscos se tornaram tão comuns que o Poder Judiciário terá que passar a considerar o binômio custo/benefício nas questões ambientais que estejam diretamente vinculadas com economia².

Tal situação se agrava na modernização reflexiva, onde as formas tradicionais de geração de energia passam a ter seu papel e importância questionados. A Sociedade de Risco se traduz em uma pressão constante no direito e na economia. O empresariado também é chamado para colaborar com a solução da crise ambiental. A responsabilidade socioambiental da empresa passa a ser exigida como uma contrapartida pelos lucros obtidos, e esta deverá buscar contribuir com a ampliação das energias renováveis.

Os princípios constitucionais ambientais, tais como da cooperação, o desenvolvimento sustentável e o do poluidor-pagador, são vetores para a troca de padrão energético, com a adoção da geração de energia através da biomassa de resíduos. Igualmente estimulam a adoção da responsabilidade socioambiental, em diversos setores, inclusive das concessões florestais. Mas para que esta possa ser vista como uma nova razão publica deve-se demonstrar que ela pode motivar a evolução da sociedade como um todo. A Rio+20 definiu a economia verde como um novo vetor, principalmente para as atividades que utilizam recursos ambientais.

O presente trabalho visa justamente analisar a possibilidade de exigência de projetos de geração de energia proveniente de biomassa de resíduos florestais nas concessões florestais. Busca-se fornecer elementos para a futura regulação da atividade, bem como para um licenciamento ambiental específico da nova técnica.

O Poder Concedente possui o poder para fixar o edital de licitação e as cláusulas dos contratos de concessão para a exploração dos recursos florestais. Embora deva respeitar os princípios da proporcionalidade/razoabilidade e da eficiência/economicidade, há um certo grau de autonomia contratual. Cabe analisar, então, se o Ministério do Meio Ambiente, conjuntamente com o Serviço

\footnotetext{
2 SUNSTEIN, Cass. Risk and reason: safety, law, and the environment. London: Cambridge University, 2002, p. 192.
} 
Florestal Brasileiro, poderiam exigir contrapartidas ambientais mais amplas, além das já tradicionalmente exigidas no edital de concessão florestal.

Não se pode esquecer que o princípio do desenvolvimento sustentável busca compatibilizar o crescimento econômico e a erradicação da miséria com a preservação ambiental.

Se a maior participação da iniciativa privada nas questões ambientais parece um caminho sem retorno, deve-se analisar a responsabilidade sócio-ambiental da empresa nas concessões florestais. Logo o objetivo central do trabalho será analisar se a biomassa de resíduos florestais pode ser exigida como

Para que tal conclusão seja alcançada na primeira seção será analisada Teoria do Risco proposta por Ulrich Beck, Anthony Giddens e Niklas Luhmann. Serão definidos os conceitos de perigo, risco e modernização reflexiva, bem como sua relação com a questão ambiental. Também serão analisados os riscos dos combustíveis fósseis.

Em seguida serão analisados os princípios constitucionais norteadores do Direito Ambiental e suas relações com a economia. O foco será mostrar como os princípios constitucionais ambientais permitem a harmonização entre o meio ambiente e as regras de mercado. Alguns princípios parecem essenciais dentre outros: os intitulados cooperação, defesa do meio ambiente, desenvolvimento sustentável e poluidor-pagador.

A terceira parte versará sobre a relação entre a história da economia e responsabilidade social da empresa. Passaremos pelas três teorias específicas de Responsabilidade Socioambiental da Empresa: a inexistência de responsabilidade, a relação entre meio ambiente e stakeholders e responsabilidade socioambiental por princípios, que inclui a modernização ecológica e a revolução necessária.

Por fim será analisada a economia ambiental colocada em prática, usando como vetor as concessões florestais e a biomassa de resíduos de madeira. Para tal serão estudadas as licitações verdes.

\section{A MODERNIZAÇÃO REFLEXIVA E A TEORIA DO RISCO}

Ulrich Beck ${ }^{3}$, sociólogo alemão, começou a formular as linhas principais de sua teoria do risco na década de 80 do século XX, influenciado por eventos como o desastre de Chernobyl, a queda do

\footnotetext{
${ }^{3}$ O sociólogo alemão desenvolve suas perspectivas sobre o risco inerente à sociedade moderna em diversas obras, porém principalmente em seu livro La sociedad del riesgo. Hacia una nueva modernidad. Barcelona: Paidós, 1998.
} 
muro de Berlim e a derrocada do modelo Welfare State. Posteriormente, sua tese foi complementada por outros autores, destacando-se Anthony Giddens ${ }^{4}$ e Niklas Luhmann.

Este último observa que preocupações com o futuro sempre foram uma constante no imaginário da sociedade. Conseqüentemente a humanidade criou categorias através das quais organizou seus temores e incertezas. Para Niklas Luhmann ${ }^{5}$, por exemplo, em eras pré-modernas o homem convivia com para os "perigos", catástrofes decorrentes de fenômenos naturais tais como pragas, tufões, incêndios e tempestades. Para contê-los, ou ao menos amenizar suas angústias, a humanidade criou uma série de práticas religiosas que transmitiam a sensação de segurança. Posteriormente a religião foi substituía pela ciência e, na tentativa de controlar as conseqüências dos perigos, a humanidade desenvolveu a técnica, o que gerou a primeira modernidade.

\section{As duas modernidades e a modernização reflexiva}

Para Giddens, o termo "modernidade" refere-se às instituições e práticas sociais que, inicialmente, podem ser observadas na Europa no período pós-feudalismo, mas que no século XX passam a ter impacto mundial. Embora possa ser associada a um período temporal e uma localização espacial inicial, estas duas características não são suficientes para esgotar e compreender o tema .

Em complementação, Ulrich Beck postula que é possível dividir a modernidade em dois períodos bem delineados. A primeira modernidade, que também pode ser denominada de simples ou industrial, tem como característica central o avanço, como o próprio nome indica, da indústria. Está ligada à existência de uma sociedade estatal e nacional, baseada nos conceitos de bem estar social, pleno emprego, estruturas coletivas. Esta primeira modernidade não apresenta qualquer preocupação com a exploração da natureza: pelo contrário, ela crê que os recursos naturais são ilimitados. Pode-se delimitar seu nascimento na Europa, no século XVII, através de várias revoluções políticas e industriais.

The two faces of risk - chance and danger - became an issue in the course of industrialization, starting with intercontinental merchant shipping. Risk represents the perceptual and cognitive schema in accordance with which a society mobilizes itself when it is confronted with openness, uncertainties and obstructions of selfcreated future and is no longer defined by religion, tradition or superior power of nature but has even lost its faith in the redemptive powers of utopias?.

\footnotetext{
${ }^{4}$ Igualmente, o sociólogo inglês, por seu turno, desenvolve sua visão sobre a Teoria do Risco em diversos textos, porém com inegável clareza em sua obra As conseqüências da modernidade. São Paulo: UNESP, 1991.

5 LUHMANN, Niklas. El futuro como riesgo. In BERIAIN, Josetxo (Comp.) Las consecuencias perversas de la modernidad. Modernidad, contingencia y riesgo. Antrophos, 1996, p. 155/172.

${ }^{6}$ GIDDENS, Anthony. As conseqüências da modernidade. São Paulo: UNESP, 1991, p. 48.

${ }^{7}$ BECK, Ulrich. World at Risk. Cambridge: Polity Press, 2010, p.04.
} 
A segunda modernidade seria a "modernização da modernização". Surge no período posterior à Segunda Guerra Mundial, e é fruto do capitalismo e do avanço tecnológico. Ela coloca em debate as antinomias e os debates da primeira modernidade: a globalização, a individualização, o desemprego, o subemprego, a revolução dos gêneros e, last but not least, os riscos globais, percebidos principalmente no desequilíbrio ecológico, nas mudanças climáticas e na crise energética ${ }^{8}$. A sociedade atual está se confrontando com os fundamentos da modernidade: este é o contexto da modernização reflexiva. Para Ulrich Beck a sociedade industrial, típica da primeira modernidade, está se desmoronando justamente graças aos seus próprios fundamentos. A sociedade atual está paulatinamente sendo transformada pelo próprio dinamismo industrial. A modernização reflexiva leva a um ambiente de inúmeros riscos, todos frutos de decisões humanas.

A crise ecológica, por exemplo, não é apenas um problema ambiental, mas uma crise institucionalizada do núcleo da modernidade, de suas idéias centrais. A sociedade industrial moderna se estabelece sobre os recursos da natureza e da cultura. Porém, sua própria dinâmica está derrubando seus alicerces. Soma-se, ainda, o relacionamento da sociedade com os riscos que esta mesma produz. Ao tomarem conhecimento das ameaças, os indivíduos são capazes de abalar as suposições básicas da ordem social tradicional, com reflexo nos negócios, no direito e na ciência. O sociólogo alemão aponta para a ocorrência desta fratura dentro do projeto moderno, a qual se desprende dos contornos da sociedade industrial clássica, e cunharia um novo modelo, o da Sociedade de Risco 9 .

\section{A sociedade de risco}

A compreensão da sociedade de risco implica em diferenciar "risco" de "perigo". Niklas Luhmann aponta, grosso modo, que os perigos existem no cotidiano, e estão fora das possibilidades de controle, da esfera de decisão. São, por exemplo, as catástrofes naturais. Já o risco é resultado de uma deliberação. Envolve uma atitude humana e remonta ao período moderno. Risco, inclusive, é uma expressão cunhada durante as navegações espanholas, e relacionava-se à possibilidade de um navio se chocar contra os rochedos, e com os novos territórios a serem explorados.

\footnotetext{
"As duas faces do risco - oportunidade e perigo - tornaram-se um problema no curso da industrialização, começando com a marinha mercante intercontinental. Risco representa o esquema perceptivo e cognitivo de acordo com a qual a sociedade se mobiliza quando é confrontada com futuras aberturas, incertezas e obstruções criadas por ela mesma e que já não são definidas por religião, tradição ou poder superior da natureza, e que perdeu até mesmo sua fé nos poderes redentores das utopias". (livre tradução).

${ }^{8}$ Cf. BECK, U.; ZOLO, D. A Sociedade Global do Risco. Tradução de Selvino J. Assmann. Entrevista disponível em http://www.cfh.ufsc.br/ wfil/ulrich.htm. Acesso em 03.07.2002.

${ }^{9} \mathrm{Cf}$. BECK, Ulrich. La sociedad del riesgo. Hacia una nueva modernidad. Barcelona: Paidós, 1998, p. 17.
} 
Assim, como já dito, o homem das sociedades pré-modernas convivia basicamente com os perigos. E visando controlar os perigos que a humanidade desenvolveu a técnica. O "risco" substitui o que antes era visto como fortuna, destino. O que a humanidade enfrenta hoje não é resultado da natureza ou intenções ocultas de deuses. Pelo contrário, os riscos são resultados das ações humanas, geralmente fruto de decisões conscientes, mas com conseqüências que fogem ao controle e que são imprevisíveis. Para Anthony Giddens, o mundo da alta modernidade é apocalíptico não porque se dirija inevitavelmente à calamidade, mas porque introduz riscos completamente desconhecidos pelas gerações anteriores ${ }^{10}$.

Risk is not synonymous with catastrophe. Risk means the anticipation of the catastrophe; Risks concern the possibility of future occurrences and developments; they make present a state of the world that does not (yet) exist. Whereas every catastrophe is spatially, temporally and socially determined, the anticipation of catastrophe lacks any spatio-temporal or social concreteness. Thus the category of risk signifies the controversial reality of the possible, which must be demarcated from merely speculative possibility, on the one hand, and from the actual occurrence of the catastrophe, on the other. The moment risk become real, when a nuclear power station explodes or a terrorist attack occurs, they become catastrophes. Risk are always future events that may occur, that threaten us $^{11}$

Principal teórico sobre o tema, Ulrich Beck ${ }^{12}$ aponta que a sociedade de risco só pode ser compreendida no contexto da modernização reflexiva. A sociedade de risco significaria um momento da segunda modernidade, onde as ameaças esboçadas pela sociedade industrial começam a tomar contornos definidos. A transição primeira para a segunda modernidade foi silenciosa e indesejada. Suas conseqüências, os riscos, surgem como efeitos colaterais latentes: levam a um momento de autoconfrontação da modernidade simples com seus fundamentos.

Pode-se virtualmente dizer que as constelações da sociedade de risco são produzidas porque as certezas da sociedade industrial (o consenso para o progresso ou a abstração dos efeitos e dos riscos ecológicos) dominam o pensamento e as ações das pessoas e das instituições da sociedade

\footnotetext{
${ }^{10}$ GIDDENS, Anthony. As conseqüências da modernidade. Trad. Raul Fiker. São Paulo: UNESP, 1991, p. 16.

${ }^{11}$ BECK, Ulrich. World at Risk. Cambridge: Polity Press, 2010, p. 09.

"Risco não é sinônimo de catástrofe. Risco significa a antecipação da catástrofe; Riscos cuidam da possibilidade de futuras ocorrências e desenvolvimentos, fazem presente estado do mundo que (ainda) não existe. Considerando que qualquer catástrofe é espacial, temporal e socialmente determinada, a antecipação de uma catástrofe não tem qualquer concretude espaço-temporal ou social. Assim, a categoria de risco significa a realidade controversa do possível, que deve ser delimitada a partir da possibilidade meramente especulativa, por um lado, e a partir da ocorrência da catástrofe real, por outro. No momento em que o risco se torna real, quando uma usina nuclear explode ou ataque terrorista ocorre, eles se tornam catástrofes. Riscos são sempre eventos futuros que podem ocorrer, que nos ameaçam". (livre tradução).
}

${ }^{12}$ Cf. BECK, Ulrich. La sociedad del riesgo. Hacia una nueva modernidad. Barcelona: Paidós, 1998, p. 17. 
industrial. A sociedade de risco não é uma opção que se pode escolher ou rejeitar no decorrer de disputas políticas. Ela surge na continuidade dos processos de modernização autônoma, que são cegos e surdos a seus próprios efeitos e ameaças. De maneira cumulativa e latente, estes últimos produzem ameaças que questionam e finalmente destroem as bases da sociedade industrial. ${ }^{13}$

\begin{abstract}
A sociedade de risco se produz pelo pensamento moderno: consenso sobre a importância do progresso a qualquer custo, abstração de efeitos e perigos ecológicos. Assim, a sociedade industrial trouxe, além do progresso econômico e social inerente aos avanços tecnológicos, uma carga global de risco. O homem, tal como o aprendiz de feiticeiro, transformou o planeta, principalmente pela atuação nos recursos naturais, e perdeu o controle durante o processo, criando a hipótese de destruição tota ${ }^{14}$. Um risco desponta não só no cenário nacional, mas também no internacional: o setor energético.
\end{abstract}

\title{
O risco energético
}

A dependência do Brasil por combustíveis derivados de petróleo e gás natural é notória. O petróleo correspondia a 39,3\% da demanda energética do país no ano de 2013, e o gás natural representou $12,8 \%$ do consumo. Mundialmente, no mesmo ano, o petróleo respondeu por $32 \%$ e o gás natural por $21 \%$ da demanda de energia ${ }^{15}$. Consumimos $3 \%$ do petróleo mundial, o equivalente a 2,80 milhões de barris por dia ${ }^{16}$. A exploração de petróleo no Brasil possui uma particularidade: 90\% de suas reservas são bacias offshore, ou seja, localizadas em mar. Tal dado influencia as questões e decisões ambientais do setor, como passará a ser abordado.

Há um consenso intuitivo sobre os impactos ambientais gerados pela indústria do petróleo. A percepção se concentra geralmente nos vazamentos ocorridos em plataformas, navios e terminais, mas outros danos são mais comuns. Cabe ressaltar que muitos não são acidentes, e sim

\footnotetext{
${ }^{13}$ GIDDENS, A.; BECK, U.; LASH; S. Modernização Reflexiva: política, tradição e estética na ordem social moderna. São Paulo: UNESP, 1997, p. 16.

${ }^{14} \mathrm{Cf}$. BECK, Ulrich. Ecological Enlightenment: essays on the politics of the risk society. New York: Humanity Books, 1994.

15 Cf EPE - EMPRESA DE PESQUISA ENERGÉTICA. Relatório Síntese Ano Base 2013. < https://ben.epe.gov.br/downloads/S\%C3\%ADntese\%20do\%20Relat\%C3\%B3rio\%20Final_2014_Web.pdf>, acesso em dezembro de 2014. Ressalte-se que até a data de fechamento deste trabalho os dados referentes à matriz energética brasileira de 2014 ainda não haviam sido divulgados.

${ }^{16} \mathrm{O}$ Brasil é o sétimo maior consumidor mundial. Cf. BARBOSA, Vanessa. Os 20 maiores consumidores de petróleo no mundo. in Exame.com. Disponível em <http://exame.abril.com.br/meio-ambiente-eenergia/noticias/os-20-maiores-consumidores-de-petroleo-no-mundo\#8>. Acesso em julho de 2013.
} 
externalidades comuns do processo produtivo do setor ${ }^{17}$. O histórico de vazamentos é o mais conhecido, mas a poluição acompanha todos os estágios de produção de óleo e gás.

Na fase do upstream há o estudo de análise sísmica, que visa fazer uma espécie de ultra-sonografia na rocha que pode armazenar o hidrocarboneto. Este afasta os cardumes, com reflexos na pesca e gera interferência com rotas de migração e períodos reprodutivos de cetáceos, tais como acasalamento e amamentação. Ainda pode causar a morte de áreas de corais.

Caso as análises sísmicas apontem alta probabilidade de existência de uma jazida de hidrocarbonetos, inicia-se a perfuração. A sonda de perfuração demanda o uso de fluidos, tanto para lubrificar e resfriar a broca quanto para levar os resíduos de rocha até a superfície. Os fluídos são poluentes, sendo formulados com componentes tais como lignossulfonatos, lignitos, poliacrilatos, tanatos, hidróxido de sódio, hidróxido de potássio, sulfato de bário, hematita, cloreto de sódio e cloreto de potássio.

Em áreas onshore a perfuração causa erosão, desmatamento e contaminação dos lençóis freáticos e aqüíferos subterrâneos com os resíduos de fluídos de perfuração e cascalho de rochas. O cascalho gerado pela perfuração é retirado para ser descartado no ecossistema. Ainda estão carregados de fluído de perfuração, e podem conter elementos como metais pesados, graxas, e sais solúveis em alta concentração. Dispersados no meio ambiente os sais acarretam a morte de plantas, já que compete com elas pela absorção de água. A chuva pode ainda carregar os sais solúveis para os lençóis freáticos profundos.

Confirmada a viabilidade da jazida para a produção de hidrocarbonetos é instalada a plataforma definitiva. Inicia-se a produção, que perdura em média vinte ou trinta anos de acordo com o volume de hidrocarbonetos na jazida. Os impactos ambientais são constantes. Há poluição sonora, atmosférica e marinha. A toxidade a que os organismos ficam expostos gera desequilíbrio nos ecossistemas. É comum o descarte de água de produção e de metais pesados. O grande trânsito de embarcações, algumas vindas do exterior, traz consigo espécies estranhas aos biomas brasileiros.

\footnotetext{
17 Os dados do presente capítulo foram retirados de seis obras. Por serem técnicos e alheios ao Direito optou-se por não transcrever trechos dos livros, e sim combiná-los e "traduzi-los" para um leitor leigo em engenharia ambiental e do petróleo.

Cf. AMUI, Sandoval. Petróleo e Gás Natural para Executivos. Rio de Janeiro: Interciência, 2010.

FAHIM, Mohammed; Al-Sahhaf, Taher. Introdução ao Refino de Petróleo. Rio de Janeiro: Campus, 2011.

FAVENNEC, Jean Pierre; BRET-ROUZAUT, Nadine. Petróleo e Gás Natural - Como Produzir e a Que Custo - 2a Ed. Rio de Janeiro: Synergia, 2011.

JAHN, Frank; COOK, Mark; GRAHAM, Mark. Introdução À Exploração e Produção de Hidrocarbonetos. Rio de Janeiro: Campus, 2013.

THOMAS, José Eduardo. Fundamentos de Engenharia de Petróleo - 2a Ed. Rio de Janeiro: Interciência, 2004. ULLER, Victor Cohen; BONFÁ, Márcio Henrique; SZKLO, Alexandre Salem. Fundamentos do Refino de Petróleo: Tecnologia e Economia - 3a Ed. Rio de Janeiro: Interciência, 2012.
} 
Os impactos sociais não se encerram na pesca. Tomemos como exemplo a Bacia de Campos, responsável por aproximadamente de $81 \%$ da produção nacional de óleo e gás. A região vem atraindo inúmeros investimentos e novos moradores. Tal migração aqueceu a economia local e multiplicou diversos setores, tais como construção civil e serviços. Mas tal prosperidade é localizada:

As estruturas econômicas e sociais evidenciam que não houve correspondência entre o visível crescimento econômico e o desenvolvimento nessa região, mostrando que dispor de recursos para investir não é condição suficiente para melhorar a situação da população, como o desenvolvimento de políticas públicas que garantam água potável, saneamento básico e atendimento médico para todos e todas as crianças na escola ${ }^{18}$.

Soma-se que a dependência energética do setor de petróleo gera um outro risco: o de instabilidade econômica. Historicamente os choques internacionais do petróleo já evidenciaram como a flutuação da cotação do petróleo influencia drasticamente a economia. Em 1973, com a Guerra do Yon Kippur, o preço do barril de petróleo passaria de US\$ 2,90 para US\$11,65. O governo brasileiro sentiu imediatamente o impacto: "o resultado foi dramático: os preços dos derivados e da economia em geral dispararam e a dependência externa de petróleo pressionou a dívida pública interna e externa. O país, um gigante, via-se em apuros ${ }^{\prime 19}$. O segundo choque do petróleo, motivado pela Revolução Iraniana em 1979, aprofundou a crise econômica no Brasil. O preço do barril do petróleo saltou de US\$13,00 para US\$34,00, com picos de US\$ 52,00. Os choques do petróleo formaram a compreensão de que o petróleo constitui um insumo estratégico. Os maiores países produtores nas últimas décadas do século XX eram instáveis politicamente, o que gerava seguidas flutuações no preço e interrupção no fornecimento. O Brasil passa a perceber que o mais seguro seria alcançar a autosuficiência em petróleo, bem como buscar outras fontes produção de energia ${ }^{20}$.

Nesse cenário as energias renováveis despontam como uma solução. O atual estágio da modernidade, segundo o projeto teórico de Beck, poderia ser exemplificado pela palavra chinesa que tanto significa "crise" como "oportunidade". A modernização reflexiva, a sociedade de risco e a subpolítica estão mudando a forma de atuação dos indivíduos, com notáveis reflexos na economia. O

\footnotetext{
${ }^{18}$ Cf. SILVA, Juliana Marsico Correia da Silva; BOZELLI, Reinaldo Luiz; SANTOS, Laísa Freire; LOPES, Alexandre Ferreira. Impactos Ambientais da Exploração e Produção de Petróleo na Bacia de Campos, RJ. In IV Encontro Nacional da Anppas. Disponível em <http://www.ebah.com.br/content/ABAAAehvoAC/impactos-ambientaisexploracao-producao-petroleo-na-bacia-campos-rj>, Acesso em setembro de 2011.

${ }^{19}$ BAUMFLEK, Imaly. O papel da OPEP no cenário internacional. In: RIBEIRO, Marilda Rosado de Sá (Org.). Estudos e Pareceres - Direito do Petróleo e Gás. Rio de Janeiro: Renovar, 2005. p. 36.

${ }^{20}$ Não se deve esquecer que outros choques do petróleo aprofundaram a crise econômica brasileira. O terceiro choque do petróleo foi causado pela Guerra do Golfo em 1990, com o aumento do preço do barril de petróleo de US\$13,00 para US\$ 42,00. Historiadores ainda debatem se um quarto choque do petróleo teria ocorrido com a Segunda Guerra do Golfo após o 11 de setembro de 2001, quando o preço do barril de petróleo saltou de US\$ 20,00 para US\$25,00, com picos de US\$ 60,00.
} 
Direito também deve se adaptar a essa nova realidade, exigindo o uso de novas alternativas energéticas pautadas pela sustentabilidade, tal como a biomassa de resíduos florestais. Neste contexto os princípios constitucionais assumem papéis centrais.

\section{PRINCÍPIOS CONSTITUCIONAIS NORTEADORES DO DIREITO AMBIENTAL E SUAS RELAÇÕES COM A ECONOMIA}

A sociedade de risco impõe novas atitudes ao Direito. A solidariedade incorpora-se ao conceito de dignidade da pessoa humana, fundando a terceira geração de direitos humanos, ou seja, a prerrogativa de todo o indivíduo a ter acesso a uma garantia material mínima, ao direito de não ser desrespeitado como pessoa - o que inclui viver em um meio ambiente hígido.

Com a Conferência do Rio de Janeiro sobre Meio Ambiente e Desenvolvimento Sustentável, realizada em 1992, a preservação do ecossistema passa a ser considerada premissa para o desenvolvimento de atividades econômicas. Sendo o meio ambiente essencial para a vida humana, as políticas estatais devem se pautar no desenvolvimento sustentado. As conseqüências da sociedade de risco são sentidas de forma cristalina no meio ambiente e uma mudança de atitude se impõe. Como alerta o Secretário-Geral do Rio-92, Maurice Frederick Strong:

do ponto de vista ambiental o planeta chegou ao ponto de não retorno. Se fosse uma empresa estaria à beira da falência, pois dilapida seu capital, que são os recursos naturais, como se eles fossem eternos. O poder de autopurificação do meio ambiente está chegando ao limite. ${ }^{21}$

O sistema normativo brasileiro reconhece a importância da economia para preservação ambiental e o desenvolvimento da sociedade. A própria Constituição da República de 1988 aponta para a necessidade de compatibilizar preservação ambiental com desenvolvimento econômico. De fato, embora a ordem econômica no Brasil seja norteada pelos princípios da livre concorrência e da livre iniciativa, a atuação do empresariado deve ser compatibilizada com os interesses ambientais e sociais, tal como transparece no artigo 170 da Constituição da República. Para Cass Sunstein os riscos se tornaram tão comuns que o Judiciário terá que passar a considerar o binômio custo/benefício nas questões ambientais que estejam diretamente vinculadas com economia ${ }^{22}$. O que, em outras palavras, significa quase todas as ações com temática ambiental, tais como composição da matriz energética. Logo, os princípios constitucionais ambientais podem ser utilizados como norte para concretizar tal

\footnotetext{
${ }^{21}$ Revista Veja, 29.05.1991, p. 9. Apud: MILARÉ, Édis, Direito do Ambiente: doutrina, prática, jurisprudência, glossário 4ạ ed. São Paulo: RT, 2005, p. 74/75.

22 SUNSTEIN, Cass. Risk and reason: safety, law, and the environment. London: Cambridge University, 2002, p. 192.
} 
tarefa. O foco será, então, mostrar como os princípios constitucionais ambientais permitem a harmonização entre o meio ambiente e as regras de mercado. Alguns princípios parecem essenciais dentre outros: os intitulados cooperação, defesa do meio ambiente, desenvolvimento sustentável, prevenção, precaução, poluidor-pagador e função socioambiental da propriedade.

\section{O princípio da cooperação}

Segundo o caput do artigo 225 da Constituição da República, o meio ambiente é "bem de uso comum do povo e essencial à sadia qualidade de vida, impondo-se ao Poder Público e à coletividade o dever de defendê-lo e preservá-lo para as presentes e futuras gerações." Logo, para a construção de um Estado de Direito Ambiental23 ${ }^{23}$ a cidadania deve ser ativa. A conscientização dos cidadãos e, conseqüentemente, do empresariado, aponta os caminhos a serem trilhados para a superação da crise ambiental. Karl-Otto Apel aponta que apenas o debate e o compartilhamento de responsabilidades podem permitir a superação de crises, tais como a ambiental ${ }^{24}$.

A Agenda 21, documento gerado pela Conferência do Rio de Janeiro sobre Meio Ambiente e Desenvolvimento Sustentável, apresenta um planejamento internacional para a superação da crise ambiental e aponta para essa necessária união entre sociedade e empresariado ${ }^{25}$. Apenas com esforço conjunto da sociedade, Poder Público e empresariado será possível atingir a meta do desenvolvimento sustentável pleno.

Logo, diversas redes de cooperação devem coexistir: entre diferentes países, na ordem internacional; internamente, entre os entes da federação brasileira, e entre práticas de mercado e ações de preservação ambiental.

\section{O princípio da defesa do meio ambiente}

A CRFB/1988 baseia-se na liberdade, inclusive no plano econômico, traduzida pelo princípio da livre iniciativa ${ }^{26}$. Tal liberdade inclui o direito do particular escolher a forma de produção, circulação de

\footnotetext{
${ }^{23}$ Cf. LEITE, José Rubens Morato. Estado de Direito do Ambiente: Uma difícil tarefa in Inovações em Direito Ambiental. Florianópolis: Fundação José Arthur Boiteux, 2000.

${ }^{24}$ APEL, Karl-Otto. Discussion et responsabilité. Paris: Cerf, 1996.

25 CONFERÊNCIA DAS NAÇÕES UNIDAS SOBRE O MEIO AMBIENTE E O DESENVOLVIMENTO. Agenda 21 3a ed. Brasília: Senado Federal, Subsecretaria de Edições Técnicas, 2000, p. 486.

${ }^{26}$ Art. 10 CRFB/1988. A República Federativa do Brasil, formada pela união indissolúvel dos Estados e Municípios e do Distrito Federal, constitui-se em Estado Democrático de Direito e tem como fundamentos: (...) IV - os valores sociais do trabalho e da livre iniciativa.
} 
mercadorias e alocação de lucros. No Brasil a produção de riquezas é incumbencia do particular, devendo o estado regular a participação na economia ${ }^{27}$.

Contudo a livre iniciativa não é absoluta, devendo respeitar a dignidade da pessoa humana, a justiça social, a valorização do trabalho humano, a redução das desigualdades sociais e a preservação ambiental. Eros Roberto Grau observa que "livre iniciativa nao se resume, aí, a 'princípio básico do liberalismo econômico' ou a 'liberdade de desenvolvimento da empresa' apenas - à liberdade única do comércio, pois. Em outros termos: não se pode visualizar no princípio tão-somente uma afirmação do capitalismo"28. O direito de propriedade privada esta ligado à liberdade. Porém tal liberdade deve respeitar o principio da solidariedade e da dignidade da pessoa humana.

O inciso VI do art. 170 CFRB $^{29}$ esculpe o princípio da defesa do meio ambiente, traduzido em um poder-dever do Estado. A Administração Pública possui a incumbência de zelar pela preservação ambiental, e para alcançar tal objetivo poderá impor políticas públicas que limitam a liberdade de atuação do empresariado. Novamente Eros Grau esclarece que:

A Constituição, destarte, dá vigorosa resposta às correntes que propõe a exploração predatória dos recursos naturais, abroqueladas sobre o argumento, obscurantista, segundo o qual as preocupações com a defesa do meio ambiente envolvem proposta de "retorno à barbárie". (...) O desenvolvimento nacional que cumpre realizar, um dos objetivos da República Federativa do Brasil, e o pleno emprego que impende assegurar supõe economia auto-sustentada, suficientemente equilibrada para permitir ao homem reencontrar-se consigo próprio, como ser humano e não apenas como um dado ou um índice econômico ${ }^{30}$.

Não há como separar materialmente preservação ambiental e economia, uma vez que a base da cadeia produtiva, a geração de matérias primas, está na natureza. Logo os artigos 170 e 225 da CRFB/1988 devem ser interpretados em conjunto. Cristiane Derani observa que "não se trata de um relacionamento em sua origem conflitante, mas apenas dois aspectos da relação entre homemnatureza, frente à imanente necessidade de expansão produtiva da atividade econômica, que se torna

\footnotetext{
27 Art. 173 CRFB/1988. Ressalvados os casos previstos nesta Constituição, a exploração direta de atividade econômica pelo Estado só será permitida quando necessária aos imperativos da segurança nacional ou a relevante interesse coletivo, conforme definidos em lei.

${ }^{28}$ GRAU, Eros Roberto A Ordem Econômica na Constituição de 1988 (interpretação e crítica) 11ạ ed. São Paulo: Malheiros, 2006, p. 202. Grifos no original.

${ }^{29}$ Art. 170 CRFB/1988. A ordem econômica, fundada na valorização do trabalho humano e na livre iniciativa, tem por fim assegurar a todos existência digna, conforme os ditames da justiça social, observados os seguintes princípios: (...) VI - defesa do meio ambiente, inclusive mediante tratamento diferenciado conforme o impacto ambiental dos produtos e serviços e de seus processos de elaboração e prestação.

${ }^{30}$ GRAU, Eros Roberto; A Ordem Econômica na Constituição de 1988 (interpretação e crítica) 11ạ ed. São Paulo: Malheiros, 2006, p. 251. Grifos no original.
} 
apropriativa, onde a natureza passa a ser exclusivamente recurso" ${ }^{31}$. Sendo o meio ambiente indisponível, tanto para o Poder Público quanto para os particulares, o princípio da defesa do meio ambiente permite que o Estado realize sempre que necessário as intervenções cabíveis para a proteção do meio ambiente.

Em suma o princípio da defesa do meio ambiente prevê a adequação do processo produtivo com as diretrizes de preservação ambiental e melhoria da qualidade de vida. Não foi outra a posição do STF $^{32}$ no julgamento da ADPF 101-DF, que versou sobre a importação de pneus remoldados e importação de pneus usados como matéria prima.

Em seu voto a Ministra Relatora Carmen Lúcia Antunes da Rocha invocou os princípios da prevenção e da precaução para decidir pela proibição da importação de pneus remoldados. Embora reconhecendo que a questão era complexa, já que as empresas do setor defendiam o argumento de respeito irrestrito à liberdade de produção e comercialização como único viés da livre iniciativa, postulando ainda defesa da geração de empregos, a Ministra observou a existência de uma nova ordem mundial, pautada no cuidado com o meio ambiente saudável em respeito até mesmo às gerações futuras. O desenvolvimento econômico é necessário, especialmente em épocas de crises financeiras. Porém seria impossível solucionar uma crise financeira com a adoção de medidas que agravassem a crise ambiental: "A fatura econômica não pode ser resgatada com a saúde humana nem com a deterioração ambiental para esta e para futuras gerações ${ }^{33 \prime \prime}$. Não é possível conceber desenvolvimento econômico pleno sem estar acompanhado de educação e saúde. O desenvolvimento previsto pela CRFB é o que leva à dignidade humana em plenitude, e não à degradação. Um trecho do voto da Ministra é especialmente esclarecedor ${ }^{34}$ :

28. O argumento dos Interessados de que haveria afronta ao princípio da livre concorrência e da livre iniciativa por igual não se sustenta, porque, ao se ponderarem todos os argumentos expostos, conclui-se que, se fosse possível atribuir peso ou valor jurídico a tais princípios relativamente ao da saúde e do meio ambiente ecologicamente equilibrado preponderaria à proteção

\footnotetext{
${ }^{31}$ DERANI, Cristiane. Direito Ambiental Econômico. São Paulo: Max Limonard, 1997, p. 191. Grifos no original

32 O STF enfrentará novamente a questão da ponderação entre defesa do meio ambiente e livre iniciativa no julgamento da ADI no 4.066-DF que versa sobre o amianto. Como o processo ainda está em andamento optou-se por não abordá-lo na presente tese.

33 Voto da Min. Relatora Carmem Lúcia, in STF, ADPF 101-DF, págs. 110, disponível em <http://redir.stf.jus.br/paginadorpub/paginador.jsp?docTP=AC\&docID=629955>; acesso em junho de 2013.

${ }^{34}$ Acompanharam o voto relator integralmente os Ministros Eros Roberto Grau, Ricardo Lewandowski, Carlos Britto e Ellen Gracie. Os Ministros Joaquim Barbosa e Gilmar Ferreira Mendes acompanharam parcialmente, concordando com a declaração do meio ambiente ecologicamente equilibrado como preceito fundamental, e com a proibição da importação de pneus remoldados ou de borracha usada como matéria prima para tal indústria.
} 
desses, cuja cobertura, de resto, atinge não apenas a atual, mas também as futuras gerações ${ }^{35}$.

O princípio da defesa do meio ambiente impõe ao Estado novas diretrizes na formulação das políticas econômicas. O Estado não deverá ser "mínimo", e sim regulador da atividade econômica, colocando-a nos trilhos para os valores constitucionais da dignidade da pessoa humana e preservação ambiental, visando o desenvolvimento sustentável${ }^{36}$.

\section{O princípio do desenvolvimento sustentável}

O conceito de desenvolvimento sustentável começa a ser formulado em 1970, com a publicação do relatório Limites do Crescimento, que ressaltava a possibilidade de escassez de recursos naturais, inclusive com a possibilidade de seu esgotamento, pela pressão causada pelos padrões de crescimento econômico estabelecidos na época. Posteriormente, em 1987, o Relatório Nosso Futuro Comum cunhou a famosa definição de desenvolvimento sustentável como sendo "aquele que atende às necessidades do presente sem comprometer a possibilidade de as gerações futuras atenderem às suas necessidades". Apesar de sugerir inovações nos padrões de consumo e produção, visando à preservação ambiental, o Relatório Brundtland considerou que o crescimento econômico ainda era necessário.

O Relatório Nosso Futuro Comum evidenciou a próxima relação entre economia e meio ambiente. A ECO-92, por seu turno, consolidou o desenvolvimento sustentável, conferindo a este força política e relevância. Durante sua realização foram assinados emblemáticos documentos, como as convenções-quadro sobre biodiversidade e mudanças climáticas, além da Agenda 21, um protocolo de compromissos que os Estados deverão adotar com o objetivo de garantir a sustentabilidade plena ao final do século 21. Porém, apesar de sua relevância, a Agenda 21 não possui valor jurídico, sendo apenas compromissória. Logo cada Nação poderá cumprir suas metas em um ritmo próprio. Por esta razão a Rio+10 ou Cúpula Mundial sobre Desenvolvimento Sustentável realizada em Johanesburgo em 2002 foi considerada um fracasso, pois se percebeu que a maioria dos países ainda não havia implementado políticas públicas centradas na sustentabilidade.

Com este precedente a Rio+20, Conferência realizada no Rio de Janeiro em 2012 voltou ao necessário debate sobre sustentabilidade, através da inclusão do conceito de economia verde. Essa pode definida como a que resulta na melhoria de bem-estar da sociedade e da igualdade social, ao

35 Voto da Min. Relatora Carmem Lúcia, in STF, ADPF 101-DF, págs. 117-118, disponível em <http://redir.stf.jus.br/paginadorpub/paginador.jsp?docTP=AC\&doclD=629955>; acesso em junho de 2013.

${ }^{36}$ Cf. SARLET, Ingo Wolfgang; FENSTERSEIFER, Tiago. Direito Constitucional Ambiental: Constituição, Direitos Fundamentais e Proteção do Ambiente 3 ed. São Paulo: RT, 2013, p. 342. 
mesmo tempo em que reduz de forma considerável os riscos e a escassez de recursos ambientais. Para tal se apóia em três pontos: a redução das emissões de gases do efeito estufa, a maior eficiência energética e no uso dos recursos naturais e a prevenção da perda da biodiversidade. Tais estratégias seriam financiadas com investimentos públicos e privados, e acompanhadas por profundas reformas políticas e regulatórias. O meio ambiente deve ser encarado como um ativo econômico essencial e foco da atuação estatal. Desta forma a economia verde poderia reduzir a pobreza persistente, mas para tal seria necessário alterar o foco dos investimentos e subsídios governamentais. Neste sentido o PNUMA aponta que:

Para se fazer a transição para uma economia verde são necessárias algumas condições facilitadoras específicas. Essas condições facilitadoras consistem de um pano de fundo de regulamentos nacionais, políticas, subsídios e incentivos, mercado internacional e infraestrutura legal e protocolos comerciais e de apoio. No momento, as condições facilitadoras incentivam e têm um peso grande na predominante economia marrom que, entre outras coisas, depende excessivamente da energia proveniente dos combustíveis fósseis. Por exemplo, os preços e os subsídios na produção de combustíveis fósseis juntos excederam o valor de US\$650 bilhões em 20086, e este alto nível de subvenções pode afetar desfavoravelmente a transição para 0 uso de energias renováveis. Em contraste, as condições possibilitadoras para uma economia verde podem pavimentar o caminho para o sucesso dos investimentos públicos e privados em tornar as economias mundiais verdes. A nível nacional, os exemplos de tais condições possibilitadoras são: mudanças na política fiscal reforma e redução de subsídios prejudiciais ao meio ambiente; emprego de novos instrumentos de base de mercado; procura de investimentos públicos para setores chave "verdes"; tornar mais verdes os contratos públicos; e a melhoria das regras e regulamentos ambientais, bem como sua execução. A nível internacional, também há oportunidades para complementar a infraestrutura de mercado, melhorar o fluxo de comércio e de apoio e promover maior cooperação internacional ${ }^{37}$.

O PNUMA sugere que os subsídios públicos e investimentos privados sejam alocados em dez áreas essenciais para tornar a economia global mais verde: agricultura, construção, pesca, silvicultura, abastecimento de energia, indústria, turismo, transportes, manejo de resíduos e água. Paralelamente os Estados devem identificar falhas de mercado, estabelecendo marcos regulatórios ou estímulos ao desenvolvimento sustentável.

\footnotetext{
37 PROGRAMA DAS NAÇÕES UNIDAS PARA O MEIO AMBIENTE. Rumo a uma economia verde: caminhos para o desenvolvimento sustentável e a erradicação da pobreza. PNUMA: 2011. Disponível em <www.unep.org/greeneconomy>. Acesso em maio de 2012.
} 
A Declaração Final da Conferência das Nações Unidas Sobre Desenvolvimento Sustentável (Rio+20) - O Futuro que queremos, apontou que a erradicação da pobreza é o maior desafio global atual, e um requisito essencial para o desenvolvimento sustentável, uma vez que é urgente libertar a humanidade da miséria e da fome. Logo impõe-se a necessidade de uma melhor integração entre a economia, os aspectos sociais e a preservação ambiental, em nome do desenvolvimento sustentável. A mudança nos modos de produção e consumo, bem como a proteção dos recursos naturais são igualmente necessários para a estruturação da sustentabilidade, bem como o estímulo ao um crescimento econômico sustentável equitativo e inclusivo. O item III da Declaração, intitulado A Economia Verde no Contexto do Desenvolvimento Sustentável e a Erradicação da Pobreza esclarece como os governos e sociedade civil devem colaborar para que a economia verde seja plenamente alcançada.

56. Afirmamos que existem diferentes abordagens, visões, modelos e ferramentas disponíveis para cada país, de acordo com suas circunstâncias e prioridades nacionais, para alcançar o desenvolvimento sustentável nas suas três dimensões, que é o nosso objetivo primordial. Neste sentido, consideramos a economia verde, no contexto do desenvolvimento sustentável e da erradicação da pobreza, como uma das importantes ferramentas, disponíveis para alcançar o desenvolvimento sustentável, que poderia oferecer opções para decisão política, sem ser um conjunto rígido de regras. Ressaltamos que a economia verde deve contribuir para a erradicação da pobreza e para o crescimento econômico sustentável, reforçar a inclusão social, melhorando o bem estar humano, e criar oportunidades de emprego e trabalho digno para todos, mantendo o funcionamento saudável dos ecossistemas da Terra.

(...)

67. Ressaltamos a importância dos governos em ter um papel de liderança no desenvolvimento de políticas e estratégias através de um processo inclusivo e transparente. Registramos também os esforços dos países, incluindo países em desenvolvimento, que já iniciaram processos para preparar estratégias nacionais de economia verde e políticas em prol do desenvolvimento sustentável.

68. Convidamos as partes interessadas, incluindo as Comissões Regionais da ONU, organizações da ONU e órgãos, outras organizações intergovernamentais pertinentes e regionais, instituições financeiras internacionais e os principais grupos envolvidos no desenvolvimento sustentável, de acordo com seus respectivos mandatos, a apoiarem os países em desenvolvimento que fizerem o pedido de alcançar o desenvolvimento sustentável, nomeadamente através das políticas de promoção de uma economia verde no contexto do desenvolvimento sustentável e da erradicação da pobreza, em particular nos países menos desenvolvidos. 
69. Convidamos também o comércio e a indústria, conforme apropriado e em conformidade com a legislação nacional, a contribuir para o desenvolvimento sustentável e a desenvolver estratégias de sustentabilidade que integrem, entre outras, as políticas de economia verde ${ }^{38}$.

Atualmente o desenvolvimento sustentável se baseia em um tripé, reforçado pela Rio+20: preservação ambiental, solidariedade intergeracional e desenvolvimento econômico e social. É sabido que há um compromisso ético entre a geração presente e as futuras de manutenção de um padrão ambiental mínimo. Nesse sentido a economia verde, tal como proposta pela Rio+20, supõe que as mudanças nos processos produtivos e na composição de bens e serviços será suficiente para a sustentabilidade.

\section{O princípio do poluidor-pagador}

O Princípio $16^{39}$ da Declaração do Rio de Janeiro sobre Meio Ambiente e Desenvolvimento de 1992 é mais comumente denominado de "poluidor-pagador". Segundo o mesmo, na ocorrência de uma ação lesiva ao meio ambiente, o poluidor deverá reparar o local degradado, fazendo retornar ao estado anterior ao atentado. É sabido que nem sempre tal situação é possível, logo o mesmo princípio pode compelir o infrator a pagar pelo próprio dano em si e por suas conseqüências para as futuras gerações. O princípio expressa uma quantificação econômica do dano ambiental, que traduz um sentido de imposição de um ônus ao degradador. Deve-se ressaltar, enfaticamente, que a adoção do princípio em tela não significa, em hipótese alguma, que poluir torna-se lícito, pois não é possível mercantilizar o meio ambiente ${ }^{40}$. Antônio Herman V. Benjamim resume a questão, ao postular que "o dano ambiental não pode, em circunstância alguma, valer a pena para o poluidor ${ }^{41}{ }^{\prime \prime}$. Não por acaso recentemente o STJ afirmou que

\footnotetext{
${ }^{38}$ CONFERÊNCIA DAS NAÇÕES UNIDAS SOBRE O MEIO AMBIENTE E O DESENVOLVIMENTO. Declaração Final da Conferência das Nações Unidas Sobre Desenvolvimento Sustentável (Rio+20). Disponível em < http://riomais20sc.ufsc.br/>, Acesso em junho de 2013, págs. 11 e 14.

39 Princípio 16: "As autoridades nacionais devem procurar promover a internacionalização dos custos ambientais e o uso de instrumentos econômicos, tendo em vista a abordagem segundo a qual o poluidor deve, em princípio, arcar com o custo da poluição, com a devida atenção ao interesse público e sem provocar distorções no comércio e nos investimentos internacionais." Apud. SILVA, Geraldo Eulálio do Nascimento e. Direito Ambiental Internacional. Meio ambiente, desenvolvimento sustentável e os desafios da nova ordem mundial. 2a edição, revista e atualizada. Rio de Janeiro: Thex, 2002, p.332.

${ }^{40}$ Cf. GUERRA, Isabella Franco; LIMMER, Flávia C. Princípios constitucionais informadores do Direito Ambiental in PEIXINHO, Manoel Messias; GUERRA; Isabella Franco; e NASCIMENTO FILHO, Firly (orgs). Os princípios da Constituição de 1988. Rio de Janeiro: Lumen Juris, 2001, p. 582 / 583.

${ }^{41}$ BENJAMIN, Antônio H. O princípio do poluidor-pagador e a reparação do dano ambiental. in Dano Ambiental, prevenção, reparação e repressão. São Paulo: RT, 1993, p. 236.
} 
nas demandas ambientais, por força dos princípios do poluidorpagador e da reparação in integrum, admite-se a condenação, simultânea e cumulativa, em obrigação de fazer, não fazer e indenizar. Assim, na interpretação do art. 3o da Lei 7.347/1985, a conjunção "ou" opera com valor aditivo, não introduz alternativa excludente. ${ }^{42}$

A visão tradicional do princípio do poluidor pagador, claramente sancionatória, já está consolidada na doutrina e jurisprudência do Brasil. Pouco a pouco outras duas acepções do princípio tomaram forma: a preventiva e, recentemente, a econômica. Além de sua cristalina faceta punitiva o princípio possui um caráter pedagógico: a sanção pecuniária deve ter valor expressivo, para que o degradador se cerque de todos os cuidados, a fim de evitar que seja cometido novamente o ato danoso ao meio ambiente. Na mesma linha, o particular é obrigado a pagar não só pela degradação já ocorrida, mas também pela poluição que possa vir a causar. Nesse caso, o empreendedor seria estimulado a adotar medidas de prevenção e precaução ao atuar em atividades potencialmente poluidoras. Sadeeler aponta que:

La principale fonction du principe consiste à internaliser le coût social que représentent pour les pouvoirs publics la prevéntion et la lutte contre la polution. Le principe apparaît à ce stade comme une règle économique d'après laquelle il faut rétrocéder une partie des bénéfices que les pollueurs tirent de leurs activités aux pouvouirs publics dont la mission est justement de contrôler, de surveiller, voire de lutter contre la pollution qu'ils émetent.

(...)

Au demeurant, la fonction purement redistributive peut faire l'objet d'une critique encore plus fondamentale. Parler du pollueur, c'est évoquer le dommage écologique, et l'énvoquer c'est se placer dans une situation où le mal a déjà été accompli, en fait dans une situation où la prévention n'a plus d'utilité. En contredisant de la sorte le principie de prévention, celui du poluerpayeur devrait donc être voué aux gémonies. Mais ces reproches doivent être nuancés dans la mesure où le principie du pollueur'payeur peut aussi (...) contribuer à la réduction de la pollution (fonction préventive) et accélérer la prise en charge des dommages écologique par leurs resonsables (fonction curative) ${ }^{43}$.

42 STJ. REsp 1145083 / MG. Segunda Turma. Ministro Relator Herman Benjamin. Julgado em 27/09/2011. Publicação em 04/09/2012.

43 SADELEER, Nicolas. Les principes du polluter-payer, de prévention et de précaution: essai sur la genése et la portée juridique de quelques principes du droit de l'environnement. Paris: Emile Bruylant, 1999, p. 66-67.

"A principal função do princípio é internalizar o custo social que a prevenção e luta contra a poluição representam para os poderes públicos. O princípio surge nesta fase como uma regra econômica que deve renunciar a uma parte dos lucros que os poluidores devem levar suas atividades para os poderes públicos, cuja missão é precisamente controlar, monitorar, ou lutar contra a poluição que eles emitem. (...)

Além disso, a função meramente redistributiva pode ser uma crítica mais fundamental. Falar do poluidor é evocar os danos ecológicos e o invocar é colocar-se em uma situação em que o dano já foi feito, de fato, em uma situação onde a prevenção não está mais em uso. Contrariando a forma como o principio da prevenção, o do 'poluidor contribuinte' deve ser de até descrédito público. Mas essas críticas devem ser qualificadas para a 
A grande questão da aplicação do princípio do poluidor-pagador reside na quantificação dos custos causados pelo dano ambiental. De fato, ainda não foi encontrada uma metodologia totalmente adequada para quantificar em termos econômicos o valor devido por um dano ambiental - por isso a importância da adoção de medidas de prevenção e precaução. Como apurar em valores pecuniários a extinção de uma espécie de fauna ou flora, as manchas de óleo em uma praia, o assoreamento de um rio? Logo, o referido princípio visa a recuperação do meio ambiente alterado pela poluição; apenas subsidiariamente será admitido o pagamento de indenização em dinheiro.

O outro aspecto do princípio em tela, mais amplo, se inspira na teoria econômica de que os custos sociais externos que acompanham o processo produtivo devem ser internalizados, observando a vocação redistribuitiva do direito ambiental ${ }^{44}$. Aquele que utiliza os bens naturais em seu processo de produção, ou que causa danos ao meio ambiente, deverá pagar. Como esclarece Cristiane Derani:

Durante o processo produtivo, além do produto a ser comercializado, são produzidas 'externalidades negativas'. São chamadas externalidades porque, embora resultantes da produção, são recebidas pela coletividade, ao contrário do lucro, que é percebido pelo produtor privado. Daí a expressão 'privatização de lucros e socialização de perdas', quando identificadas as externalidades negativas. Com a aplicação do princípio do poluidor-pagador, procura-se corrigir este custo adicionado à sociedade, impondo-se sua internalização ${ }^{45}$.

Para tal teoria não é cabível que a sociedade suporte o ônus de recuperação da degradação causada por uma atividade cujo lucro será individualizado. Permitir tal prática equivaleria a autorizar o enriquecimento ilícito. O custo social da poluição deve ser suportado pelo empreendedor que aufere ganhos financeiros com a prática poluidora ${ }^{46}$. Patrícia Faga Iglecias Lemos complementa:

Em outras palavras, estaremos diante de uma externalidade negativa toda vez que parte dos custos decorrentes da produção e do consumo de um bem forem direcionados para indivíduos alheios a esta cadeia de produção e consumo. No caso dos recursos ambientais, podemos afirmar que haverá uma externalidade negativa toda vez que um impacto ambiental gerado pela produção e pelo consumo não for suportado pelos agentes diretamente beneficiados pela atividade produtiva. Isso significa que os custos ambientais estarão sendo transferidos para a

extensão do principio 'poluidor contribuinte' pode também (...) contribuir para a redução da poluição (preventiva) da função e acelerar o gerenciamento de danos ecológicos e de seus responsáveis (função curativa)". (livre tradução).

${ }^{44}$ Cf. MILARÉ, Édis, Direito do Ambiente: doutrina, prática, jurisprudência, glossário 4ạ ed. São Paulo: RT, 2005, p. 100/101.

${ }^{45}$ DERANI, Cristiane. Direito Ambiental Econômico. São Paulo: Max Limonard, 1997, p. 158. Grifos no original.

46 PRIEUR, Michel. Droit de l'environnement. 5 ed. Paris: Dalloz, 2004, p. 145. 
coletividade, tendo-se em vista que os bens ambientais são de uso comum do povo ${ }^{47}$.

Essa posição já foi aceita pelo Brasil, através da adoção da tese da responsabilidade pósconsumo ${ }^{48}$, onde o empreendedor deverá arcar com os custos da poluição causada pelas embalagens de seus produtos. A Lei da Política Nacional de Resíduos Sólidos, Lei no 12.305/2010, inova ao estabelecer a responsabilidade compartilhada na gestão de resíduos.

Os princípios de Direito Ambiental apontam para a necessidade de novas formas de atuação do empresariado. A responsabilidade socioambiental surge com força, como uma proposta de atendimento à economia verde.

\section{A POSSIBILIDADE DE ADOÇÃO DA RESPONSABILIDADE SOCIOAMBIENTAL ATRAVÉS DA BIOMASSA DE RESÍDUOS}

É inegável que as pressões econômicas alteram as características dos ecossistemas. As práticas de mercado e as escolhas dos consumidores influenciam na decisão de preservar ou não um ecossistema, bem como adotar ou não medidas de precaução. Tal conceito se coaduna com a Teoria da Análise Econômica do Direito defendida por Ronald Coase e Richard Posner pressupõe que os indivíduos são racionais, logo suas escolhas buscam maximizar seu próprio interesse ${ }^{49}$. Assim, reagem a incentivos, tais como prêmios e punições, e suas ações acarretam conseqüências que afetam também a terceiros. Nessa lógica a legislação também pode ser vista como um estímulo externo, e quanto mais as normas forem próximas às instituições sociais, mais eficiente será o sistema ${ }^{50}$. O acervo legal deve se aproximar da economia visando o aperfeiçoamento das decisões judiciais. Tal concepção tem reflexos diretos nas questões ambientais.

O meio ambiente sofre pressões de acordo com as escolhas dos empreendedores e do público consumidor. Sendo assim novas práticas relacionadas com a questão da preservação do meio ambiente devem ser debatidas. Uma das falhas do modelo teórico da sociedade de risco é que ele não apresenta soluções para as crises, especialmente a ambiental. Este vácuo permitiu que outras teorias

47 LEMOS, Patrícia Faga Iglecias. Resíduos Sólidos e Responsabilidade Civil Pós-Consumo 2a Ed. São Paulo: RT, 2012.

${ }^{48}$ Cf. A decisão do Tribunal de Justiça do Estado do Paraná na Apelação Cível no 118.652-1/ Curitiba, Rel. Des. Ivan Bortoleto.

${ }^{49}$ CARVALHO, Cristiano de. Princípios e Conseqüências: a teoria da escolha racional como critério de ponderação - Introdução ao problema. Disponível em http://www.viadesignlabs.com/lawandeconomics/Principios_e_Consequencias.pdf $>$. Acesso em julho de 2008.

${ }^{50}$ SZTAJN, Rachel. Law and Economics. In: ZYLBERSZTAJN, Décio, e SZTAJN, Rachel. Direito e Economia: análise econômica do Direito e das Organizações. Rio de Janeiro: Elsevier, 2005. 
surgissem, tais como as que sugerem que a economia pode ser a ferramenta mais eficiente para a superação dos atuais problemas ambientais.

Definir responsabilidade socioambiental da empresa, contudo, não é uma tarefa simples. O conceito é recente e dinâmico, e sujeito aos mais diversos tipos de definições. Para alguns se limita à geração de riquezas e, conseqüentemente, empregos. Já um conceito mais moderno se foca na implantação de ações visando o bem-estar da coletividade, promovidas pelas empresas.

\section{A Responsabilidade Socioambiental da Empresa: conceitos e teorias}

Tema da moda, a responsabilidade socioambiental vem encontrando ferrenhos defensores, tanto no empresariado quanto no governo e na sociedade em geral. Trata-se da percepção que a empresa está situada em um ambiente social, estabelecendo relações com diversos públicos, cujos interesses devem ser considerados, tais como funcionários, fornecedores, clientes, acionistas, governo, concorrentes, meio ambiente e comunidade. $\mathrm{O}$ atendimento a estes setores deverá ser a linha condutora das políticas empresariais. Não se trata da simples consideração às exigências legais, e sim (ao menos em tese) a preocupação na geração de valor para todos ${ }^{51}$. Patrícia Ashley define responsabilidade social como sendo:

o compromisso que uma organização deve ter com a sociedade, expresso por meio de atos e atitudes que a afetem positivamente, de modo amplo, ou a alguma comunidade, de modo específico, agindo proativamente e coerentemente no que tange a seu papel específico na sociedade e a sua prestação de contas para com ela. A organização, nesse sentido, assume obrigações de caráter moral, além das estabelecidas em lei, mesmo que não diretamente vinculadas as suas atividades, mas que possam contribuir para o Desenvolvimento Sustentável dos povos. Assim, numa visão expandida, Responsabilidade Social é toda e qualquer ação que possa contribuir para a melhoria da qualidade de vida da sociedade ${ }^{52}$.

Logo, a responsabilidade socioambiental da empresa poderia ser definida como a obrigação de promover o bem estar da sociedade, através da adoção de uma atitude ética em todas as suas ações, visando o desenvolvimento sustentável.

\footnotetext{
${ }^{51}$ Cf. GRAJEW, Oded. Instituto Ethos. Disponível em: <http://www.ethos.org.br>. Acesso em agosto de 2007.

52 ASHLEY, Patrícia Almeida. Ética e responsabilidade social nos negócios. São Paulo: Saraiva, 2002, p. 6.
} 
Os problemas ambientais, para esta linha, não significam apenas oportunidades de negócios. As empresas são parte da sociedade e carregam consigo a responsabilidade de colaborar na solução da crise ambiental. Para a visão da responsabilidade socioambiental baseada em princípios de nada adiantaria uma empresa bem sucedida economicamente em um planeta falido social e ambientalmente. A busca pelo desenvolvimento sustentável garantiria, portanto, a própria existência da empresa a longo prazo.

Frente aos questionamentos impostos pela sociedade de risco, urge a necessidade de encontrar soluções. Nesse ponto, deve-se, ao menos, questionar se o modelo capitalista de produção pode ser utilizado como uma ferramenta para a superação da crise ambiental. Seria possível, em algum momento, alcançar o modelo do desenvolvimento sustentável? Poderia existir alguma empresa que conciliasse, de forma plena, a busca pelo lucro com a preservação ambiental?

Em tempos não tão remotos, os bens ambientais foram protegidos unicamente pelo seu valor econômico ${ }^{53}$. No caso brasileiro, este raciocínio pode ser identificado desde a colonização, até aproximadamente a década de 70, do século XX (embora não seja difícil encontrar defensores desta linha até o momento atual). As Ordenações Afonsinas e Manuelinas instituíram normas que tipificavam como crime o corte de árvores frutíferas e o furto de árvores. Apesar de indiretamente protegerem o meio ambiente, o real objetivo destas normas era proteger o patrimônio do rei. O revogado Código Civil de 1916 seguia a mesma linha economicista e liberal ${ }^{54}$. Segundo este viés antropocêntrico, recursos ambientais abundantes, tais como a água, eram taxados de "bens economicamente livres" ${ }^{55}$, e poderiam ser usados sem limite, pois não possuíam qualquer valor financeiro. Já bens finitos ou com pouca oferta possuíam valor econômico, devendo a lei tutelá-los. A preocupação do legislador não era com a preservação ambiental, mas simplesmente com a manutenção do patrimônio privado.

A partir da segunda metade do século passado, inúmeros acidentes ambientais, tais como os ocorridos em Love Canal, Valdez, Bhopal e Chernobyl${ }^{56}$, apontaram que o meio ambiente seria essencial não só para a manutenção da economia, mas para a própria salubridade e dignidade da vida

\footnotetext{
53 WAINER, Ann Helen. Legislação ambiental brasileira: evolução histórica do Direito Ambiental. In Revista de Direto Ambiental $n^{\circ}$ 0. São Paulo: RT, p 14.

54 Podemos citar, como exemplos, os artigos 593, 567 e 598.

55 Cf. CALDERONI, Sabetai. Economia Ambiental in PHILIPPI JR., Arlindo; ROMÉRO, Marcelo de Andrade; BRUNA, Gilda Collet. Curso de Gestão Ambiental. São Paulo: Manole, 2004, p. 575.

${ }^{56}$ Inúmeros desastres ambientais ocorreram no Brasil, com lamentáveis conseqüências para o meio ambiente e perdas humanas, tais como Cidade dos Meninos em Duque de Caxias. Porém apenas aqueles com impacto mundial foram citados no corpo o texto, pois influenciaram a realização de conferências internacionais sobre meio ambiente.
} 
humana. Soma-se, ainda, o surgimento de um novo paradigma, biocêntrico, que aponta para a necessidade da preservação do meio ambiente por si só ${ }^{57}$.

Com a Conferência de Estocolmo sobre o Meio Ambiente, em 1972, solidificou-se nas legislações de diversos países o conceito de que a manutenção do meio ambiente hígido é essencial para a dignidade humana ${ }^{58}$. Posteriormente, um novo conceito foi incorporado ao Direito Ambiental: o desenvolvimento sustentável, introduzido pelo Relatório Nosso Futuro Comum ${ }^{59}$, da Organização das Nações Unidas, e reafirmado pela Conferência do Rio de Janeiro sobre o Meio Ambiente e o Desenvolvimento de 1992.

A intervenção praticamente sem controle do ser humano na natureza, praticada em larga escala durante séculos, levou à escassez de recursos ambientais e às diversas catástrofes, muitas delas irreversíveis. A necessidade de equilibrar desenvolvimento econômico e preservação ambiental tornou-se evidente. O desenvolvimento sustentável pode ser visto como o modelo de produção que não cria obstáculos para a qualidade de vida das gerações presentes e futuras.

O desenvolvimento sustentável, porém, parece ser o grande nó górdio da civilização atual: de um lado, é patente a evidência que o modo de produção adotado até agora causa uma descontrolada degradação ambiental. De outro, a necessidade da economia avançar, para que recursos financeiros sejam gerados, e o desenvolvimento social seja possível. É conhecida a hipótese levantada pelas Nações Unidas em 1992, durante a Conferência do Rio de Janeiro, que se todo ser humano fosse alçado ao mesmo padrão de consumo de um americano de classe média, os recursos naturais do planeta se extinguiriam em poucos anos, menos de uma década - previsão talvez otimista se for considerado que o meio ambiente sequer resiste às agressões no atual patamar. O modo de vida de uma pequena parcela da população mundial só é possível porque a maior parte vive abaixo da linha da miséria. Vê-se, então, um problema praticamente sem solução: é inviável permitir que bilhões ${ }^{60}$ de

${ }^{57}$ Cf. BORGES, Roxana Cardoso Brasileiro. Direito Ambiental e teoria política no final do séc. XX. In VARELLA, Marcelo Dias; BORGES, Roxana Cardoso Brasileiro (Orgs). O novo em Direito Ambiental. Belo Horizonte: Del Rey, 1998, p. 11-32; e SILVA, José Robson. Paradigma Biocêntrico: do patrimônio privado ao patrimônio ambiental. Rio de Janeiro: Renovar, 2002.

58 Cf. SOARES, Guido Fernando Silva. Direito Internacional do Meio Ambiente: emergência, obrigações e responsabilidades. São Paulo: Atlas, 2000, p. 56-57; e SILVA, Geraldo Eulálio do Nascimento. Direito Ambiental Internacional: meio ambiente, desenvolvimento sustentável e os desafios da nova ordem mundial. Rio de Janeiro: Thex, 2002, p. 27-32. Pode-se citar, ainda, a interessante decisão da Corte Européia de Direitos Humanos no caso López Ostra, bem como a posição o Supremo Tribunal Federal no ADI-MC 3540 / DF, Julg. 01/09/2005, Min. Relator Celso de Mello.

${ }^{59}$ THE WORLD COMMISSION ON ENVIRONMENT AND DEVELOPMENT. Our common future. New York: Oxford University, 1987.

${ }^{60}$ Por exemplo, em 1999, cerca de 2,8 bilhões de pessoas (duas entre cada cinco no planeta) sobreviviam com menos de US\$ 2 por dia, o que as Nações Unidas e o Banco Mundial classificam como o mínimo necessário para atender às necessidades básicas. Aproximadamente, 1,2 bilhão de pessoas viviam em "extrema pobreza", 
seres humanos continuem a viver sem o respeito à dignidade. Porém, se em um passe de mágica os mesmos indivíduos recebessem o ingresso para a sociedade de consumo típica, os recursos naturais não suportariam tal impacto ${ }^{61}$. Esta problemática, típica da modernização reflexiva e da sociedade de risco, exige a busca imediata por soluções.

Simplesmente eliminar o consumo não parece ser viável: o homem sempre terá necessidades materiais. Soma-se, ainda, que o consumo mantém a indústria, e esta é a maior geradora de empregos. Certamente, podemos defender um padrão de consumo mais ético e consciente: o consumidor é peça essencial para a preservação do meio ambiente ${ }^{62}$. Porém, a grande chave para a solução da crise ambiental, ao que parece, encontra-se nas formas de produção, na atuação da indústria e das instituições financeiras. Se em um primeiro momento o meio ambiente foi protegido apenas por seu valor econômico, não seria à hora da economia zelar pelo meio ambiente, simplesmente por esse último ser essencial para a humanidade?

\section{A economia ambiental colocada em prática: concessões florestais e biomassa de resíduos}

Também não parece surreal afirmar que a ampliação do setor privado é cada vez mais marcante no Brasil. Novas legislações apontam para, ao que parece, uma união sem volta entre mercado e Poder Público ${ }^{63}$. É possível identificar em um primeiro estágio privatizações ${ }^{64}$, seguidas por delegações da prestação de serviços públicos ${ }^{65}$, e por uma comunhão de forças entre estas duas

medida por uma renda diária média de menos de US\$ 1. Em ambos os casos, o consumo dos participantes desta lamentável estatística se limita a bens essenciais para a sobrevivência. (Cf. WORLDWATCH INSTITUTE. State of the world 2004: special focus the consumer society. New York: W. W. Norton \& Company, 2004, p. 5.)

61 Embora o fosso existente de renda e consumo per capita existente entre países classificados como "desenvolvidos" e "em desenvolvimento" esteja se aprofundando, apenas o impacto do aumento de população esperado já é suficiente para selar a crise ambiental. Por exemplo, a Organização das Nações Unidas projeta que a população mundial atingirá 8,9 bilhões até 2050. Apenas este crescimento, isolado de qualquer outra variável, é suficiente para eliminar a economia de energia obtida até o presente momento com o uso de equipamentos mais eficientes. (CF. WORLDWATCH INSTITUTE. State of the world 2004: special focus the consumer society. New York: W. W. Norton \& Company, 2004, p. XXIII e 6.)

${ }^{62}$ O capítulo 4 da Agenda 21 visa justamente estimular a adoção do consumo sustentável. Cf. CONFERÊNCIA DAS NAÇÕES UNIDAS SOBRE O MEIO AMBIENTE E O DESENVOLVIMENTO. Agenda 21 3a ed. Brasília: Senado Federal, Subsecretaria de Edições Técnicas, 2000, p. 39.

${ }^{63}$ Nicolau Dino de Castro e Costa Neto critica tal modelo, por significar uma diminuição da soberania estatal, pois "transfere seu conceito para o âmbito de mercado". (COSTA NETO, Nicolau Dino de Castro. Direito e Neoliberalismo in Revista de Informação Legislativa, $n^{\circ} 160$, p. 191-221, out./dez. 2003.)

${ }^{64}$ Lei $n^{\circ}$ 9.491/1997

${ }^{65}$ Lei $n^{\circ}$ 8.987/1995 e Lei n 9.074/1995. 
diferentes categorias, tal como nas parcerias público-privadas ${ }^{66}$, mas ainda com uma determinada supervisão estatal. Porém inexiste a possibilidade de em um segundo momento o Estado se retirar por completo de inúmeros setores, transferindo-os, ainda que de maneira informal, para a iniciativa privada: a Administração Pública continuaria a ser detentora do poder de polícia ${ }^{67}$, mas o mercado poderia colaborar as ações de promoção social e, inclusive, um mecanismo mínimo de autofiscalização.

No caso específico da área ambiental é possível usar como exemplo deste raciocínio o Sistema Nacional de Unidades de Conservação (previsto na Lei n 9.985 de 2000) e a Lei de Gestão de Florestas (Lei $n^{\circ} 11.284$ de 02 de março de 2006), que prevê o mecanismo de gestão de áreas florestais públicas. Deve-se levar em conta que a preservação ambiental, durante muito tempo, foi considerada responsabilidade exclusiva do Poder Público. De fato, a responsabilidade civil objetiva por dano ambiental só pode ser identificada no Direito brasileiro a partir da publicação da Lei n 6.938 de 1981 (Lei da Política Nacional do Meio Ambiente). Antes deste marco a obrigação de reverter à degradação ambiental não estava clara. Por exemplo: no caso de dúvida sobre qual, dentre várias empresas do mesmo ramo de atividade situadas em certa região, era o responsável pelo dano ao meio ambiente, não se falava em responsabilidade solidária: o in dúbio pro réu seria aplicado.

Se, em um primeiro momento, a única atuação do particular na questão ambiental se restringia à correção dos danos por ele causados, a adoção de medidas de prevenção e precaução passou a ser progressivamente exigida. Nesse caso, outro passo pode ser identificado: não basta recuperar os danos causados, o empreendedor deve arcar com os custos da minimização de impactos ambientais, ainda que os mesmos sejam tolerados pela lei68 - tal raciocínio está presente inclusive na recente decisão do Supremo Tribunal Federal sobre a constitucionalidade da compensação ambiental

\footnotetext{
66 Instituídas pela Lei $n^{\circ} 11.079$ de 30 de dezembro de 2004, as parcerias público-privadas visam atrair investimentos do setor privado para projetos de infraestrutura de grande porte, e que extrapolem a capacidade financeira do Estado. Nesse caso, o parceiro privado recebe a garantia de um retorno mínimo do capital investido, assegurada através do pagamento de uma contraprestação pela Administração Pública. A gestão do empreendimento, via de regra, é destinada ao parceiro privado.

${ }^{67}$ De fato, o Brasil passou a adotar uma corrente formalista para definir serviço público, uma vez que atividades vitais, tal como saúde e educação, são fornecidas por particulares e serviços secundários (tais como postal e loterias) são prestados pelo Estado. O próprio Supremo Tribunal Federal divide a prestação de serviços públicos em propriamente estatais - ligados à soberania estatal e, portanto, indelegáveis, tais como a prestação jurisdicional - e serviços públicos essenciais ao interesse público, que podem ser transferidos aos particulares. (Cf. STF, RE 89.876, Rel. Min. Moreira Alves)

${ }^{68}$ O sistema brasileiro prevê a existência de "limites toleráveis de poluição": o Poder Público pode fixar normas de emissão e padrões, que representam uma fronteira a não ser ultrapassada. Mas isso não significa que o empreendedor não deva adotar medidas necessárias para diminuir ao máximo a degradação ambiental causada pelo seu empreendimento.
} 
prevista pela Lei no 9.9985 de $2000^{69}$. Quando o Sistema Nacional de Unidades de Conservação reconhece a importância das Reservas Particulares do Patrimônio Natural (RPPN) trata-se de um novo raciocínio - as ações do particular podem, efetivamente, complementar as políticas ambientais do Poder Público, tal como prevê o princípio da cooperação. Para melhor compreensão deste raciocínio, impõe-se uma análise, ainda que breve, do disposto na lei n 9.985/2000.

Cumprindo o comando do art. $225, \S 1^{\circ}$ da CRFB $/ 198^{70}$, foi criado o Sistema Nacional de Unidades de Conservação. Deve-se ressaltar que o conceito de áreas protegidas pelo Poder Público já existia no Brasil. Contudo não havia um texto normativo que sistematizasse e unificasse a questão. A Lei n 9.985/2000 veio justamente para atender a estes objetivos, criando um novo sistema de áreas protegidas. Porém a lei do SNUC inovou ao pautar a conservação da natureza com outros objetivos, tais como o desenvolvimento sustentável das áreas e o apoio às comunidades tradicionais.

Logo as unidades de conservação são áreas dotadas de atributos especiais, que justificam sua proteção. Nesse sentido a Lei $n^{\circ}$ 9.985/2000 inovou ao dividir as Unidades de Conservação em dois grupos: as de Proteção Integral e as de Uso Sustentável. Enquanto as primeiras visam precipuamente à preservação da natureza e só admitem uso econômico indireto, as segundas - como o próprio nome indica - visam cumprir com o postulado pelo princípio do Desenvolvimento Sustentável, unindo uso econômico direto com preservação ambiental. A atividade econômica responsável não só é permitida como deve ser estimulada neste ultimo grupo. Logo a preservação da natureza é garantida, mas será compatibilizada com o desenvolvimento econômico da área e a efetiva participação das populações tradicionais na gestão da área.

Neste novo modelo, e entre as Unidades de Uso sustentável destaca-se a Floresta Nacional FLONA, conceituada no art. 17 da Lei n 9.985/2.000. São áreas dotadas de cobertura vegetal nativa, e que possuem como objetivo central a exploração sustentável dos recursos florestais conjugada à permanência, subsistência e atendimento aos interesses das populações tradicionais.

De certo que não se pode ignorar o valor econômico das florestas, bem como da extração de madeira. Porém o acesso descontrolado aos recursos florestais gera efeitos nocivos, tais como o desmatamento, a desertificação, a grilagem e a expulsão da população tradicional. A Lei de Gestão de

\footnotetext{
${ }^{69}$ STF, ADI 3.378/DF. Pleno. Min. Rel. Carlos Britto. Julgada em 09.04.2008.

70 Art. 225. Todos têm direito ao meio ambiente ecologicamente equilibrado, bem de uso comum do povo e essencial à sadia qualidade de vida, impondo-se ao Poder Público e à coletividade o dever de defendê-lo e preservá- lo para as presentes e futuras gerações.

$\S 1$ ㅇ - Para assegurar a efetividade desse direito, incumbe ao Poder Público:

III - definir, em todas as unidades da Federação, espaços territoriais e seus componentes a serem especialmente protegidos, sendo a alteração e a supressão permitidas somente através de lei, vedada qualquer utilização que comprometa a integridade dos atributos que justifiquem sua proteção
} 
Florestas visa combater tais problemas, permitindo o desenvolvimento da economia local de forma sustentável, não predatória e gerando renda e emprego para as comunidades. Para tal foi criado do sistema de concessão florestal. A própria Lei n 11.284 de 2006 coloca como objetivos, em seu art. $2^{\circ}$ :

Art. 2 - Constituem princípios da gestão de florestas públicas:

I - a proteção dos ecossistemas, do solo, da água, da biodiversidade e valores culturais associados, bem como do patrimônio público;

II - o estabelecimento de atividades que promovam o uso eficiente e racional das florestas e que contribuam para o cumprimento das metas do desenvolvimento sustentável local, regional e de todo o País;

III - o respeito ao direito da população, em especial das comunidades locais, de acesso às florestas públicas e aos benefícios decorrentes de seu uso e conservação;

IV - a promoção do processamento local e o incentivo ao incremento da agregação de valor aos produtos e serviços da floresta, bem como à diversificação industrial, ao desenvolvimento tecnológico, à utilização e à capacitação de empreendedores locais e da mão-de-obra regional;

$\checkmark$ - o acesso livre de qualquer indivíduo às informações referentes à gestão de florestas públicas, nos termos da Lei n_10.650, de 16 de abril de 2003;

VI - a promoção e difusão da pesquisa florestal, faunística e edáfica, relacionada à conservação, à recuperação e ao uso sustentável das florestas;

VII - o fomento ao conhecimento e a promoção da conscientização da população sobre a importância da conservação, da recuperação e do manejo sustentável dos recursos florestais;

VIII - a garantia de condições estáveis e seguras que estimulem investimentos de longo prazo no manejo, na conservação e na recuperação das florestas.

O texto normativo prevê três formas de exploração sustentável das florestas: gestão direta pelo Poder Público; destinação de áreas florestais para o uso comunitário das populações locais extrativistas; e por fim a concessão de florestas de domínio público, que será o foco. Esta última modalidade permite que o empreendedor privado explore, mediante delegação onerosa contratual e precedida por processo licitatório, os produtos e serviços florestais. Não há transferência de domínio da área, porém o concessionário ficará responsável pelos atos praticados nela. No contrato o Ministério do Meio Ambiente figura como Poder Concedente; e o Serviço Florestal Brasileiro como órgão gestor. Cabe a este último, conforme o art. 53 da Lei n 11.284/2006, elaborar o Plano Anual de Outorga Florestal, acompanhar o procedimento licitatório, fixar e fiscalizar os preços florestais, dentre outras atribuições.

O instituto da concessão florestal, norteado pelo princípio do desenvolvimento sustentável, sem dúvida é inovador. Possui como objeto a exploração de produtos e serviços florestais, em área 
limitada e definida pelo Poder Público. Não há, assim, transferência de domínio, mas apenas a autorização de manejo para exploração de produtos florestais. Não é permitido o acesso aos recursos genéticos, pesqueiros, da fauna silvestre, minerais e a outorga de água.

Como visto cabe ao Serviço Florestal Brasileiro elaborar, anualmente, o Plano Anual de Outorga Florestal - PAOF; que será definido pelo Poder Concedente. Este conterá a descrição das florestas públicas que poderão ser oferecidas em concessão durante a sua vigência, destacando as prioritárias $^{71}$. O PAOF baseia a concessão, permitindo o planejamento da produção florestal.

A concessão florestal será precedida por processo licitatório na modalidade concorrência, regulado pela própria Lei de Gestão de Florestas (seções VI a VII) e subsidiariamente pela Lei $n^{\circ}$ 8.666/1993. A escolha seguirá os critérios de técnica e preço. A melhor técnica resultará da combinação de menor impacto ambiental na área ofertada, maiores benefícios sociais diretos, maior eficiência e, por fim, maior eficiência na agregação de valor ao produto ou serviço florestal na região da concessão $0^{72}$

A Lei $n^{\circ} 11.284$ segue uma tendência cada vez mais sentida no Brasil: a transferência de serviços públicos para as mãos do particular, ainda que supervisionada atentamente pelo Estado. Um novo modelo de gestão de Unidades de Conservação ${ }^{73}$, as Florestas Públicas poderão ser administradas diretamente pelo Estado, ou por pessoa jurídica de direito privado. Este último através de contrato de concessão, sendo escolhido mediante prévia licitação. O particular poderá explorar economicamente a área sob sua responsabilidade, respeitando os critérios de preservação ambiental. Interessante observar, inclusive, que um dos principais critérios de seleção entre os licitantes será o de desenvolvimento sustentável:

Art. 26. No julgamento da licitação, a melhor proposta será considerada em razão da combinação dos seguintes critérios:

I - o maior preço ofertado como pagamento ao poder concedente pela outorga da concessão florestal;

II - a melhor técnica, considerando:

a) o menor impacto ambiental;

b) os maiores benefícios sociais diretos;

c) a maior eficiência;

d) a maior agregação de valor ao produto ou serviço florestal na região da concessão.

\footnotetext{
${ }^{71}$ Cf. art. 11 da Lei n. 11.284/2006

72 Cf. art 26 da Lei de Gestão de Florestas.

$73 \mathrm{O}$ artigo $4^{\circ}$ da referida Lei prevê três formas de utilização para as Florestas Públicas, com foco na produção sustentável: criação de unidades de conservação, na modalidade florestas nacionais; uso comunitário, tais como assentamentos florestais, reservas extrativistas e áreas quilombolas; e concessão florestal onerosa, com escolha do particular através de sistema de licitação pública. A própria Administração Pública federal poderá administrar a área, sendo facultada a possibilidade de convênios, termos de parceria, contratos ou instrumentos similares, para que terceiros se ocupem das atividades subsidiárias.
} 
Em um admirável encontro com as propostas da modernização ecológica, o sistema de gestão de florestas poderia, em uma perspectiva otimista, abrir novos postos de trabalho, tanto diretos quanto indiretos. Cabe ressaltar que o mercado financeiro também seria beneficiado, pois a Lei em tela prevê a contratação de garantias ${ }^{74}$, tais como, dentre outras, seguros e fiança bancária.

Andréa Struchel e Élson Roney Servilha observam que países que exploraram suas áreas florestais com enfoque puramente econômico perceberam uma riqueza em um primeiro momento, mas posteriormente a devastação gerou conseqüências graves para o solo, tais como desertificação e erosão ${ }^{75}$. É justamente o que a Lei de Gestão de Florestas busca evitar, ao impor que a necessária exploração madeireira seja feita sob atenta supervisão estatal ${ }^{76}$.

Esta breve análise da Lei de Gestão de Florestas se faz necessária para comprovar a linha de raciocínio seguida por este estudo: o sistema jurídico brasileiro permite que a iniciativa privada colabore ativamente com Estado, inclusive exercendo funções de preservação ambiental muito além das exigidas pela lei. Na mesma linha o Poder Público pode exigir cada ver mais que o particular atue na promoção de práticas sociais e ambientais, ainda que isto não esteja expressamente previsto em normas infraconstitucionais. Essa exigência não será, necessariamente, oficial: se o Poder Público abandonar determinadas áreas, estas poderão ser ocupadas pela iniciativa privada, tal como prevê a cartilha da modernização ecológica, seja por interesse econômico ou por preocupação genuína.

Deve-se explicitar, aqui, que não se trata de uma visão ingênua, onde todos os empreendedores passariam a adotar e defender a causa ambiental. O capitalismo tende a ser predatório. Se por vezes é necessário defendê-lo das próprias práticas de mercado (a exemplo da limitação da concorrência), na preservação do meio ambiente a regulação pelo Direito e pela Administração Pública é essencial.

A Lei de Gestão de Florestas visa assim combater a extração ilegal de madeira, o trabalho escravo, o desmatamento e a migração da população tradicional. A exploração sustentável das Florestas Nacionais é feita através de contratos de concessão precedidos de licitação. Ao envolver as

\footnotetext{
74 As garantias visam cobrir eventuais danos causados ao meio ambiente, ao erário e a terceiros e, em determinados casos, a cobertura do desempenho do concessionário em termos de produção florestal. Seu valor deverá ser compatível com os ônus e riscos envolvidos nos contratos de concessão florestal. São aceitos como garantias: caução em dinheiro; títulos da dívida pública, seguro-garantia; fiança bancária; outras admitidas em lei.

75 STRUCHEL, Andréa; SERVILHA, Elson Roney. O direito, a lei e a gestão de florestas. In Revista de Direito Ambiental, v. 46, p. 31, abril-junho, 2007.

76 O novo sistema de gestão de florestas merece constantes estudos, cada vez mais aprofundados, pois possui força para se tornar cada vez mais corriqueiro. Por ser norma geral, os demais entes da federação poderão exercer a competência suplementar e, respeitado o princípio da simetria, autorizar a exploração de terras estaduais e municipais segundo o mesmo mecanismo. Logo, a tendência é que o mecanismo também seja utilizado por estados e municípios.
} 
comunidades locais no processo, garante a manutenção da cultura, das formas de viver e do bem estar da população.

\section{Concessões Florestais para a Geração de Biomassa}

A atual crise ecológica, resultante da Sociedade de Risco, impõe a busca de novas soluções. Como já explicitado o setor energético não só multiplica os riscos já existentes - a exemplo da crise econômica; como produz novos, tais como o aquecimento global. O cenário internacional de escassez do petróleo, as pressões ambientais causadas pela queima de combustíveis fósseis tornam cristalina a necessidade de novas soluções. E se risco pode significar oportunidade as energias renováveis despontam como uma alternativa. Uma proposta demanda maior atenção: o uso da biomassa.

O uso da biomassa não pode ser desprezado na busca pela autonomia energética. A diversificação da matriz é essencial, ainda mais levando-se em conta as pressões ambientais pelo abandono do uso de combustíveis fósseis. O possível cenário de escassez do petróleo, um bem finito, somado aos já vistos impactos desta indústria, apontam para a necessidade de novas soluções. A diversificação, especialmente a baseada em energias alternativas e sustentáveis, permite maior segurança uma vez que minimiza os impactos econômicos causados pela flutuação do preço do O\&G no cenário internacional.

Mesmo com esse contexto favorável a utilização da biomassa gerada a partir de matérias orgânicas ainda é tímida no Brasil, o que chama a atenção, uma vez que a extensão territorial e a exuberante biodiversidade constituem diferenciais positivos para esse setor. Embora $41 \%$ da oferta de energia interna no Brasil seja oriunda de fontes renováveis, o setor hidráulico constitui a maior fatia (37,1\% em 2013). A energia gerada por lenha e carvão vegetal correspondeu a $24,6 \%$, e as outras renováveis a $12,3 \%$ no mesmo ano ${ }^{77}$.

De uma forma simples é possível definir biomassa como a quantidade de matéria orgânica presente em um composto. A Directiva 2001/77/CE define biomassa como: "a fracção biodegradável de produtos e resíduos da agricultura (incluindo substâncias vegetais e animais), da floresta e das indústrias relacionadas, bem com a fracção biodegradável dos resíduos industriais e urbanos" 78 .

77 Cf EPE - EMPRESA DE PESQUISA ENERGÉTICA. Relatório Síntese Ano Base 2013. < https://ben.epe.gov.br/downloads/S\%C3\%ADntese\%20do\%20Relat\%C3\%B3rio\%20Final_2014_Web.pdf>, acesso em dezembro de 2014. Ressalte-se que até a data de fechamento deste trabalho os dados referentes à matriz energética brasileira de 2014 ainda não haviam sido divulgados.

${ }^{78}$ Directiva 2001/77/CE do Parlamento Europeu e do Conselho, de 27 de Setembro de 2001, relativa à promoção da electricidade produzida a partir de fontes de energia renováveis no mercado interno da electricidade. Disponível em < http://eur-lex.europa.eu/legal-content/PT/TXT/?uri=CELEX:32001L0077>. Acesso em dezembro de 2014. 
Quando queimada a biomassa é capaz de gerar gases que são transformados em energia. A energia de biomassa é gerada através de processos de gaseificação, de pirólise ou de produção de briquetes ou péletes para posterior combustão ${ }^{79}$. Por exemplo, combustão direta de madeira (lenha, carvão vegetal), resíduos agrícolas e resíduos urbanos.

Deve-se ressaltar que há dois tipos de biomassa energética: a tradicional, que utiliza lenha e outros resíduos naturais; e a moderna, produzida com tecnologias sustentáveis, tais como florestas plantadas e resíduos agrícolas ${ }^{80}$. A biomassa tradicional pode levar ao desmatamento descontrolado. Soma-se que uma das críticas ao modelo energético baseado na biomassa consiste na possível diminuição da fronteira agrícola para a produção de alimentos. Nesse sentido a biomassa produzida através de resíduos se apresenta com uma alternativa mais correta.

O resíduo, como sabido, constitui a sobra de um processo de produção, exploração, transformação ou utilização. É toda a substância ou material destinado, a princípio, ao abandono. Dar outra destinação para os resíduos configura a alternativa tecnológica mais racional e ecológica para a produção de combustível. Nesse sentido a Associação Nacional das Empresas Florestais, Agrícolas e do Ambiente de Portugal desta que:

A utilização energética da biomassa representa assim, no contexto florestal, uma forma de aumentar a eficiência dos recursos disponíveis, promovendo o desenvolvimento do sector; a viabilidade econômica dos sistemas agro-florestais pelo associativismo e emparcelamento, contrariando e penalizando o seu abandono; constituindo mais um ponto a favor do ordenamento e da gestão florestal sustentável imprimindo-lhe coerência e a integração desde a floresta até a indústria e simultaneamente garantindo a conservação dos recursos ${ }^{81}$.

A biomassa produzida por resíduos florestais desponta como uma alternativa economicamente viável e sustentável, ainda mais em um cenário de aumento progressivo dos impactos ambientais e sociais causados pelo uso de combustíveis fósseis. Este novo modelo é especialmente atrativo em razão do endurecimento legislativo sobre a questão do lixo, através da promulgação da Lei de Gestão de Resíduos Sólidos - Lei n 10.305/2010. Como visto o princípio do poluidor pagador, que inspirou a criação do texto normativo, impõe a responsabilidade pós consumo.

\footnotetext{
79 Cf. WIECHETEK, Marcelo. Aproveitamento de Resíduos e Subprodutos Florestais, Alternativas Tecnológicas e Propostas de Políticas ao Uso de Resíduos florestais para Fins Energéticos. Brasília: Ministério do Meio Ambiente, 2009, $\quad$ pág. $09 . \quad$ Disponível em <http://www.mma.gov.br/estruturas/164/_publicacao/164_publicacao10012011033501.pdf>. Acesso em dezembro de 2014.

80 LEAL, Manoel Regis Lima Verde. O potencial de aproveitamento da energia de biomassa. In Inovação UNIEMP v. $1 \mathrm{n}^{\circ}$ 03. Campinas: UNIEMP, 2005.

${ }^{81}$ ANEFA. Biomassa Florestal Oportunidade e Valor. Lisboa: ANEFA, 2011. Disponível em <http://www.anefa.pt>. Acesso em dezembro de 2014.
} 
A Política Nacional de Resíduos Sólidos promulgada em 2010 inova ao basear o manejo dos resíduos em critérios de sustentabilidade, visando o aumento progressivo do uso da reciclagem e da reutilização dos mesmos. Dois pontos merecem destaque: a responsabilidade compartilhada e a logística reversa.

A responsabilidade compartilhada se pauta no princípio ambiental da cooperação, ao prever que a sociedade e o empresariado devem se unir ao Poder Público na correta gestão de resíduos. Os três setores devem colaborar a redução dos impactos ambientais e da geração de resíduos e sólidos e do desperdício de materiais, bem como no desenvolvimento de novos mercados de produção de derivados de materiais recicláveis e negócios dotados de responsabilidade socioambiental.

Por seu turno a logística reversa prevê obrigações ao empresariado, impondo a responsabilidade pós consumo. As embalagens e subprodutos devem ter destinação ambiental adequada, seja pela reciclagem ou pelo reaproveitamento em novos ciclos produtivos.

O ideal para o empreendedor, sem dúvida, será unir a nova obrigação com uma nova alternativa de geração de lucros ou de responsabilidade socioambiental. A indústria madeireira não utiliza toda a lenha produzida para fins comerciais. Especialmente uma a casca do tronco e os galhos mais finos são descartados como resíduos florestais. A serragem, os cavacos, as pontas de toras e a serragem, porém, possuem potencial energético que não pode ser desprezado.

É possível classificar os resíduos da indústria madeireira em serragem, cepilho, sólidos de madeiras e casacas. A indústria de celulose e papel gera cavacos e lodo industrial, que contém fibras de madeira. É surpreendente, porém, que diversos setores desta indústria simplesmente desconheçam o potencial energético destes subprodutos. Como aponta Marcelo Wiechetek:

Em termos gerais, observou-se falta de informações e estatísticas sobre a real participação de resíduos de madeira na matriz energética nacional e regional, bem como seu potencial para fins energéticos. Os institutos e associações que trabalham com o tema ainda não estão estruturados e faltam estatísticas regulares e comparáveis sobre o tema.

Os levantamentos de campo também apontaram um déficit de informação referente à possibilidade de gerar energia elétrica a partir da queima dos resíduos de madeira por parte de muitos madeireiros, notadamente na região Norte do país.

(...)

Devido a este déficit de informação, os resíduos de madeira são considerados como um problema/ passivo industrial, e não como fonte de redução de custos e como oportunidade de geração de renda." $" 82$.

${ }^{82}$ Cf. WIECHETEK, Marcelo. Aproveitamento de Resíduos e Subprodutos Florestais, Alternativas Tecnológicas e Propostas de Políticas ao Uso de Resíduos florestais para Fins Energéticos. Brasília: Ministério do Meio Ambiente, 
O resíduo é visto como um problema a ser contornado, e não como uma possível fonte de renda, ou ao menos redução de custos, já que a energia gerada pela biomassa pode ser usada para alimentar a própria demanda energética da empresa ${ }^{83}$.

A biomassa proveniente de resíduos florestais possui desvantagens, tais como menor poder calorífico (se comparada ao petróleo), maior possibilidade de emissão de material particulado e custo considerável de equipamentos. Porém possui baixo custo para aquisição, ou mesmo custo zero caso se utilize as aparas do próprio processo produtivo da empresa. Representa considerável economia, uma vez que possui potencial para gerar energia suficiente para suprir toda demanda industrial, tornando a empresa auto-suficiente do ponto de vista energético. Seu impacto ambiental é inferior do que os combustíveis fósseis, uma que é um combustível renovável, suas cinzas são menos agressivas e não há emissão de dióxido de enxofre ${ }^{84}$. Há assim total atendimento aos princípios ambientais, e aos princípios de disposição ambientalmente correta dos resíduos sólidos e logística reversa.

Tal como a Lei de Gestão de Resíduos Sólidos, a Lei de Gestão de Florestas Públicas pauta-se pelos princípios ambientais do Desenvolvimento Sustentável, Defesa do Meio Ambiente e Cooperação. A exploração dos recursos vegetais deverá ser feita de forma equilibrada e responsável, tanto ecologicamente quanto socialmente, o que não significa um óbice para o lucro e desenvolvimento econômico. Nada mais natural, então, que a união dos dois institutos, estimulando a produção da biomassa de resíduos madeireiros nas áreas sob concessão florestal.

No contexto da responsabilidade socioambiental e da valorização das populações tradicionais, a biomassa adquire ainda mais valor, pois é uma forma sustentável de geração de energia para comunidades tradicionais e de baixa renda. Como é sabido as florestas nacionais, via de regra, estão localizadas em áreas de baixa densidade populacional. Logo apresentam baixos índices de eletrificação, em razão do elevado custo de instalação de equipamentos para o atendimento de

2009, $\quad$ pág. $26 . \quad$ Disponível $\quad$ em <http://www.mma.gov.br/estruturas/164/_publicacao/164_publicacao10012011033501.pdf>. Acesso em dezembro de 2014.

${ }^{83}$ Cf. WIECHETEK, Marcelo. Aproveitamento de Resíduos e Subprodutos Florestais, Alternativas Tecnológicas e Propostas de Políticas ao Uso de Resíduos florestais para Fins Energéticos. Brasília: Ministério do Meio Ambiente, 2009, $\quad$ pág. $06 . \quad$ Disponível em <http://www.mma.gov.br/estruturas/164/_publicacao/164_publicacao10012011033501.pdf>. Acesso em dezembro de 2014.

${ }^{84}$ Cf. GRAUER, Andreas; KAWANO, Mauricy. Vantagens da Biomassa na Produção de Energia. Disponível em < http://ambientes.ambientebrasil.com.br/energia/biomassa/vantagens_da_biomassa_na_producao_de_energia. html>. Acesso em dezembro de 2014. 
poucos consumidores, o que se torna economicamente inviável. A população utiliza geradores de pequeno porte movidos a diesel, o que possui elevado custo ambiental e econômico ${ }^{85}$.

Tais regiões poderiam, então, passar a utilizar a energia gerada por biomassa de resíduos florestais como alternativa, o que certamente cumpriria com o designado pelo princípio do Desenvolvimento Sustentável. Pode-se debater, como se verá adiante, a inclusão de regras editalícias que confiram pontuação ao empreendedor que ser prontificar a fornecer o equipamento de geração de energia, bem como os resíduos, para a população tradicional. Soma-se que geraria novos postos de trabalho, incremento da renda para a comunidade local.

A falta de energia impede o desenvolvimento de atividades produtivas, economicamente organizadas e potencialmente geradoras de emprego e renda, sobrevivam no interior da Amazônia, levando à pobreza, à exclusão social e à migração dos jovens em busca de estudo e trabalho. Este fato tem reflexo direto nas condições de vida e no Índice de Desenvolvimento Humano (ID H) dessa região. O suprimento de energia elétrica para comunidades isoladas é, então, uma das formas de proporcionar melhorias nas condições de vida da população e inserção social, mediante a possibilidade de atrelar atividades produtivas à geração de energia ${ }^{86}$.

Contudo a energia produzida por biomassa deve atender corretamente aos princípios ambientais. Caso contrário esta forma de geração de energia poderá estimular o desmatamento descontrolado das florestas nativo, gerando redução da biodiversidade e desertificação. Nesse contexto a biomassa oriunda de resíduos vegetais se destaca como a alternativa mais correta, ainda mais quando obtida sob supervisão e controle do Estado, tal como pode ocorrer na concessão florestal. Nesse sentido a atuação do Serviço Florestal Brasileiro é crucial. Um instituto pode contribuir para a exigência da correta disposição dos resíduos florestais para a produção de biomassa nos editais de concessões florestais: as licitações verdes.

\section{Licitações verdes}

\footnotetext{
${ }^{85}$ VELÁZQUEZ, Silvia Maria Stortini; SANTOS, Sandra Maria Apolinario; MOREIRA, José Roberto; COELHO, Suani Texeira. A Geração de Energia Elétrica em Comunidades Isoladas da Amazônia a partir de Biomassa Sustentável: Projeto ENERMAD. Disponível em <http://cenbio.iee.usp.br/download/publicacoes/xiiicbe_enermad.pdf>. Acesso em dezembro de 2014.

${ }^{86} \mathrm{Ibid}$.
} 
O poder de compra e de contratação do Estado pode ser uma preciosa ferramenta para alcançar o desenvolvimento sustentável, uma vez que aloca expressivos recursos. E pode influenciar o comportamento do setor privado, ao estabelecer padrões mínimos de qualidade ambiental para seus potenciais fornecedores. As compras estatais tornam-se, assim, capazes de alcançar resultados que vão muito além da simples transação comercial, já que o Estado sinaliza que a sustentabilidade será uma demanda imposta definitivamente, ou ao menos por longo prazo, ao setor privado. Desta forma as externalidades negativas tendem a ser internalizadas, para que a empresa não corra o risco de perder a lucrativa oportunidade de contratar com a Administração Pública. A Agenda 21 já esclareceu que:

8.27. As leis e regulamentações ambientais são importantes, mas não podem por si só pretender resolver todos os problemas relativos a meio ambiente e desenvolvimento. Preços, mercados e políticas fiscais e econômicas governamentais também desempenham um papel complementar na determinação de atitudes e comportamentos em relação ao meio ambiente ${ }^{87}$.

Sendo a licitação uma ferramenta do Poder Público para garantir a escolha da proposta mais vantajosa para a sociedade, o critério de sustentabilidade deve estar sempre presente, visando não só a proteção ambiental como também o desenvolvimento econômico e social.

A licitação sustentável parte dos princípios e práticas tradicionais de boa contratação, acrescendo novos critérios para maximizar benefícios socioambientais, sendo "uma solução para integrar considerações ambientais e sociais em todos os estágios do processo da compra e contratação dos agentes públicos (de governo) com o objetivo de reduzir impactos à saúde humana, ao meio ambiente e aos direitos humanos" ${ }^{88}$. Porém como as orientações políticas não são suficientes para incluir critérios sustentáveis a normatização mostrou-se necessária.

Com o fortalecimento do princípio do desenvolvimento sustentável a Administração Pública passou a analisar a implementação de uma política de compras sustentáveis. Em 1994 a Lei no 8.666/1993 foi alterada, passando a considerar o impacto ambiental dos projetos de obras e serviços públicos ${ }^{89}$. Posteriormente, em 2009, foi promulgada a Lei № 12.187, que institui a Política Nacional Sobre Mudança do Clima. O texto impõe o estímulo e apoio à manutenção e à promoção de padrões sustentáveis de consumo; bem como a adoção de medidas para a mitigação das mudanças climáticas,

87 CONFERÊNCIA DAS NAÇÕES UNIDAS SOBRE O MEIO AMBIENTE E O DESENVOLVIMENTO. Agenda 21 ३a ed. Brasília: Senado Federal, Subsecretaria de Edições Técnicas, 2000, p.75.

${ }^{88}$ BIDERMAN, Rachel. et al. Guia de compras públicas sustentáveis: Uso do poder de compra do governo para a promoção do desenvolvimento sustentável. 2a. ed. São Paulo: ICLEI, 2008, p. 25.

${ }^{89}$ Art. 12 da Lei 8.666/1993. Nos projetos básicos e projetos executivos de obras e serviços serão considerados principalmente os seguintes requisitos: (...)

VII - impacto ambiental. 
dentre as quais o estabelecimento de critérios de preferência nas licitações e concorrências públicas para as propostas que propiciem maior economia de energia, água e outros recursos naturais e redução da emissão de gases do efeito estufa e de resíduos ${ }^{90}$. Por fim em 2010 a Lei da Política Nacional de Resíduos Sólidos estabeleceu a prioridade nas aquisições e compras governamentais de produtos reciclados, além de bens, serviços e obras que levem em consideração critérios compatíveis com padrões de consumo social e ambientalmente sustentáveis ${ }^{91} \mathrm{~A}$ listagem de dispositivos legais, embora entediante, é necessária para a confirmação da nova visão de sustentabilidade imposta à Administração Pública, facultando aos gestores o estabelecimento de novos critérios para as aquisições e contratações. O art. 37, XXI da CRFB/1988 impõe que os contratos públicos devem via de regra, ser precedidos pela licitação, logo é necessária a compatibilização da preservação ambiental com o crescimento econômico desejado.

Mas a dificuldade para a concretização desta idéia está justamente na falta de diretrizes mais sólidas e critérios objetivos, que permitissem ao administrador público valorar o impacto ambiental dos vencedores de uma licitação sem frustrar a competitividade. Por esta razão em 2010 o Ministério do Planejamento, Orçamento e Gestão publicou a Instrução Normativa no 01, que dispõe sobre os critérios de sustentabilidade ambiental para a contratação de serviços ou obras e aquisição de bens no âmbito do Poder Público Federal, visando à economia da manutenção e operacionalização da edificação, a redução do consumo de energia e água, bem como a utilização de tecnologias e materiais que reduzam o impacto ambiental, inclusive impondo o uso obrigatório de agregados reciclados nas obras contratadas, sempre que existir a oferta de agregados reciclados, capacidade de suprimento e custo inferior em relação aos agregados naturais.

Porém o ponto mais polêmico da Instrução Normativa consiste na possibilidade de exigência da certificação ISO 14.000:

Art. 40 Nos termos do art. 12 da Lei no 8.666, de 1993, as especificações e demais exigências do projeto básico ou executivo, para contratação de obras e serviços de engenharia, devem ser elaborados visando à economia da manutenção e operacionalização da edificação, a redução do consumo de energia e água, bem como a utilização de tecnologias e materiais que reduzam o impacto ambiental, tais como:

$(\ldots)$

$\S 4$ ㅇ No projeto básico ou executivo para contratação de obras e serviços de engenharia, devem ser observadas as normas do Instituto Nacional de Metrologia, Normalização e Qualidade Industrial - INMETRO e as normas ISO no 14.000 da Organização

\footnotetext{
${ }^{90}$ Cf. Art. 50, XIII "b" e art. 60 XII da Lei no 12.187/2009.

${ }^{91}$ Cf. art. 70, XI "a" e "b" da Lei no 12.305/2010.
} 
Internacional para a Padronização (International Organization for Standardization).

$\S 5$ Q Quando a contratação envolver a utilização de bens e a empresa for detentora da norma ISO14000, o instrumento convocatório, além de estabelecer diretrizes sobre a área de gestão ambiental dentro de empresas de bens, deverá exigir a comprovação de que o licitante adota práticas de desfazimento sustentável ou reciclagem dos bens que forem inservíveis para o processo de reutilização.

Como visto, há dúvidas se as certificações ISO poderiam ser usadas como critério para a habilitação dos concorrentes. A redação dos parágrafos do artigo quarto, transcritos acima, não esclarece se a exigência de apresentação do certificado só será obrigatória para as empresas já detentoras do selo ISO 14.000. Tal dúvida se agrava com a análise do art. 5ำ § 10 da mesma Instrução Normativa, onde resta claro que é admitida a exigência de certificações, embora não esclareça se estas serão critério de pontuação ou de habilitação dos licitantes:

Art. 50 Os órgãos e entidades da Administração Pública Federal direta, autárquica e fundacional, quando da aquisição de bens, poderão exigir os seguintes critérios de sustentabilidade ambiental:

I - que os bens sejam constituídos, no todo ou em parte, por material reciclado, atóxico, biodegradável, conforme ABNT NBR 15448-1 e 15448-2;

II - que sejam observados os requisitos ambientais para a obtenção de certificação do Instituto Nacional de Metrologia, Normalização e Qualidade Industrial - INMETRO como produtos sustentáveis ou de menor impacto ambiental em relação aos seus similares;

(...)

$\S 1$ A comprovação do disposto neste artigo poderá ser feita mediante apresentação de certificação emitida por instituição pública oficial ou instituição credenciada, ou por qualquer outro meio de prova que ateste que o bem fornecido cumpre com as exigências do edital.

Tendo em vista que a Administração Pública muitas vezes é responsável por significativos impactos ambientais na execução de obras, especialmente as de infraestrutura, a Lei 8.666/1993 foi modificada para atender às exigências do desenvolvimento sustentável, impondo um novo objetivo às licitações:

Art. 3o A licitação destina-se a garantir a observância do princípio constitucional da isonomia, a seleção da proposta mais vantajosa para a administração e a promoção do desenvolvimento nacional sustentável e será processada e julgada em estrita conformidade com os princípios básicos da legalidade, da impessoalidade, da moralidade, da igualdade, da publicidade, da probidade administrativa, da vinculação ao instrumento convocatório, do julgamento objetivo e dos que lhes são correlatos. ${ }^{92}$

\footnotetext{
${ }^{92}$ A Lei no 8.666/1993 foi alterada pela Lei no 12.349/10, em 15 de dezembro de 2010. Grifamos.
} 
Esta alteração legislativa inaugura as licitações sustentáveis: a inserção de critérios socioambientais se torna um vetor nas compras e contratações realizadas pelo Poder Público, visando à maximização de valor e mitigação dos impactos ambientais. Acompanhando a mudança foi editado o Decreto no 7.746/2012, que regulamenta as licitações verdes, e estabelece critérios, práticas e diretrizes para a promoção da sustentabilidade nas contratações realizadas pela Administração Pública Federal. Para tal foi criada a Comissão Interministerial de Sustentabilidade na Administração Pública CISAP.

O Decreto autoriza a contratação levando em conta critérios de sustentabilidade, que deverão ser definidos no edital de licitação. Os padrões deverão ser objetivos, e serão enquadrados como especificação técnica ou obrigação da empresa contratada ${ }^{93}$.

O TCU já havia considerado, ao combinar o art. 10 da Lei da Política Nacional do Meio Ambiente com o art. 12 da Lei de Licitações, que nas obras e serviços que possam gerar impacto ambiental significativo a Licença Prévia deverá estar incluída no projeto básico da obra, para que as medidas de redução de danos ao meio ambiente já estejam computadas no custo da obra, e seja de conhecimento prévio dos licitantes.

Representação formulada por Secretaria de Fiscalização de Obras apontou possíveis irregularidades no Edital da Concorrência 1/2012 - TRE/RJ, lançado pelo Tribunal Regional Eleitoral no Estado do Rio de Janeiro para contratação da execução das obras de construção do edifício-sede desse órgão. Entre as ocorrências relacionadas, destaque-se, inicialmente, a ausência de licença ambiental prévia (LP) para o empreendimento. Verificou-se que o pedido de licença havia sido dirigido à Prefeitura Municipal do Rio de Janeiro na mesma data da publicação do edital (17/5/2012). A unidade técnica ressaltou, porém, que o projeto básico somente poderia ter sido elaborado após a obtenção da respectiva licença prévia. Ponderou, a esse respeito, que "o projeto básico deve obrigatoriamente conter as licenças ambientais requeridas, devendo ainda compreender o estudo de impacto ambiental antecipadamente determinado...". Garante-se, com isso, que "o empreendimento

93 Decreto no 7.746/2012.

Art. 2ㅇ A administração pública federal direta, autárquica e fundacional e as empresas estatais dependentes poderão adquirir bens e contratar serviços e obras considerando critérios e práticas de sustentabilidade objetivamente definidos no instrumento convocatório, conforme o disposto neste Decreto.

Parágrafo Único. A adoção de critérios e práticas de sustentabilidade deverá ser justificada nos autos e preservar o caráter competitivo do certame.

Art. 3o Os critérios e práticas de sustentabilidade de que trata o art. 2o serão veiculados como especificação técnica do objeto ou como obrigação da contratada. 
seja concebido e orçado levando-se em conta as medidas mitigadoras, compensatórias e/ou corretivas do meio ambiente, em cumprimento ao disposto na legislação aplicável, qual seja: art. 10 da Lei 6.938/1981; art. 6o, inciso IX, c/c o art. 12, inciso VII, da Lei 8.666/1993 e o art. 8o, inciso I, da Resolução/Conama 237/1997". A relatora do feito, ao endossar a análise da unidade técnica, ressaltou que a jurisprudência do TCU é pacífica no sentido que "a Licença Prévia (LP) deve existir antes da instauração da licitação, pois o atendimento das exigências ambientais é determinante na própria concepção do objeto". Ao avaliar a pertinência de adoção da medida cautelar sugerida na representação, considerou que tal omissão configura, juntamente com outros indícios de irregularidades identificados, o requisito da fumaça do bom direito. O perigo na demora, por sua vez, resulta da previsão de entrega dos documentos pelas licitantes para 18/6/2012 e da iminente assinatura de contrato provavelmente viciado. A relatora, então, também por esse motivo, decidiu determinar a suspensão cautelar da Concorrência 1/2012 - TRE/RJ e promover a oitiva do órgão. 0 Tribunal, em seguida, endossou essa providência. Precedentes mencionados: Acórdãos nọs. 2.886/2008, 1.580/2009, 1.620/2009, 1.726/2009, 2.013/2009, 2.367/2009, 870/2010 e 958/2010, todos do Plenário e 5.157/2009 da 2a Câmara

Cabe lembrar que o critério de oferta mais vantajosa para a Administração Pública não é apenas financeiro, ou seja, de menor preço, mas abarca também a qualidade do produto ou serviço, sendo mais favorável e adequada ao interesse governamental. E neste ponto fica claro que a oferta mais vantajosa no processo licitatório deve seguir um padrão adicional: a sustentabilidade ambiental. Como há um grau de discricionariedade na escolha da melhor oferta as questões ambientais passam a ser um fator a ser ponderado no juízo de oportunidade e conveniência.

Como o Poder Público é um dos maiores consumidores de bens e serviços no Brasil o uso da licitação verde é um instrumento essencial para alcançar o desenvolvimento sustentável. Nesse sentido, a adoção do critério de responsabilidade socioambiental geraria externalidades positivas para a sociedade.

Um dos instrumentos que o Serviço Florestal Brasileiro poderia utilizar para impor a destinação dos resíduos florestais para a produção de energia oriunda de biomassa nas concessões florestais seria a inclusão desta regra em editais das próximas ofertas de concessão florestal. Para se estudar a viabilidade deste novo requisito é possível traçar um paralelo com a legalidade de clausulas editalícias que exigem certificações, tais como a ISO 9.000.

A rigor a documentação necessária para a habilitação dos licitantes está restrita ao art. 27 da Lei ํo 8.666/1993: 
Art. 27. Para a habilitação nas licitações exigir-se-á dos interessados, exclusivamente, documentação relativa a:

I. habilitação jurídica;

II. qualificação técnica;

III. qualificação econômico-financeira;

IV. regularidade fiscal e trabalhista;

V. cumprimento do disposto no inciso XXXIII do art. 7o da Constituição Federal.

A rigor a exigência de certificação não está contemplada no artigo supra, logo a exigência de tal documento como essencial para a habilitação ou qualificação certamente feriria o princípio da legalidade. Porém a certificação poderia ser exigida no edital como item de pontuação, a ser somado na nota técnica. De fato o Tribunal de Contas da União entendeu que a exigência de apresentação da certificação ISO iria restringir a competição nas licitações, uma vez que afastaria os participantes não certificados. Mas ressaltou que não haveria óbice para que o certificado fosse utilizado para conferir pontuação à empresa licitante, uma vez que isso permitiria reconhecer seu diferencial em relação a outras que não comprovaram a adequação de seu sistema de produção aos critérios de qualidade estabelecidos em tais normas ${ }^{94}$. Como a exigência de certificação fere o princípio da legalidade estrita, os critérios de sustentabilidade e de responsabilidade socioambiental da empresa devem estar presentes nos projetos básicos formulados pelo Poder Público, mas não podem configurar nos editais como critério de habilitação ou classificação dos licitantes. Contudo a certificação poderia ser utilizada como critério de pontuação da proposta técnica. Soma-se, ainda, que as licitações verdes estão claramente em consonância com os artigos 170 e 225 da CRFB/1988. O TCU estabelece que:

O administrador tem a faculdade de exigir a certificação do produto em relação à norma escolhida, desde que devidamente fundamentado no processo licitatório, mediante parecer técnico, devendo ser aceitos os certificados emitidos por qualquer entidade acreditada pelo Instituto Nacional de Metrologia, Normalização e Qualidade Industrial (Inmetro) para tal ${ }^{95}$.

Como a Lei de Gestão de Florestas prevê que o julgamento da licitação na concessão obedecerá ao critério de melhor técnica resultante da combinação de menor impacto ambiental na área ofertada, maiores benefícios sociais diretos, maior eficiência e, por fim, maior eficiência na agregação de valor ao produto ou serviço florestal na região da concessão; seria possível que a adoção de ações de responsabilidade socioambiental fosse somada a este último quesito. Igualmente o plano

94 Cf. TCU, Acórdão no 1.612/2008-Plenário, julgado em abril de 2011 . Disponível em <http://portal2.tcu.gov.br/portal/page/portal/TCU/jurisprudencia/informativos/info_licitacoes/Informativo\%20d e\%20Licita\%C3\%A7\%C3\%B5es\%20e\%20Contratos\%20n\%C2\%BA\%20060_2011.doc>. Acesso em maio de 2012.

95 TCU, Acórdão 2.392/2006, julgado em junho de 2006. Disponível em <www.tcu.gov.br/Consultas/Juris/Docs/judoc/.../022-022-2005-5-ASC.doc>. Acesso em maio de 2012. 
de trabalho do concessionário poderia incluir as ações que ele se comprometeria a desenvolver ou apoiar nas áreas sociais e ambientais. A própria Lei de Gestão de Florestas esclarece em seu artigo 31, XVII que é obrigação do concessionário realizar os investimentos ambientais e sociais definidos no contrato de concessão florestal.

Por fim o mesmo texto normativo, no art. 55, deixa cristalino que cabe ao Serviço Florestal Brasileiro estimular e fomentar a prática de atividades florestais sustentáveis madeireiras, propor planos de produção florestal sustentável de forma compatível com as demandas da sociedade. Observa-se assim que há arcabouço não só teórico, mas também forte amparo legislativo para a plena inclusão da obrigatoriedade da destinação dos resíduos florestais para a produção de biomassa energética nos contratos de concessão florestal.

\section{CONCLUSÃO}

O contexto da modernização reflexiva e da teoria do risco impõe uma série de debates. A crise ecológica tão marcante como risco é, na verdade, um reflexo da crise do núcleo da modernidade. Os riscos envolvem uma atitude humana, geralmente fruto de decisões conscientes, mas com conseqüências que fogem ao controle e que são imprevisíveis.

Ulrich Beck esclarece que a sociedade de risco só pode ser compreendida no contexto da modernização reflexiva, um momento da segunda modernidade, onde as ameaças esboçadas pela sociedade industrial começam a tomar contornos definidos. Logo dialoga constantemente com o pensamento moderno: há um consenso sobre a importância do progresso a qualquer custo, juntamente com obscurecimento dos efeitos sofre o meio ambiente.

A sociedade de risco impõe um debate sobre a regulação ambiental, uma vez que gera alterações na forma de atuação dos indivíduos, com notáveis reflexos na economia. O Direito também deve se adaptar a essa nova realidade. Neste contexto os princípios constitucionais assumem papéis centrais. Especialmente na possível aplicação da responsabilidade socioambiental da empresa os princípios norteadores do Direito Ambiental permitem a harmonização entre o meio ambiente e as regras de mercado. Alguns princípios parecem essenciais dentre outros: os intitulados cooperação, defesa do meio ambiente, desenvolvimento sustentável, e poluidor-pagador.

O princípio da cooperação mostra a necessidade de um esforço conjunto da sociedade, Poder Público e empresariado para poder se alcançar a meta do desenvolvimento sustentável pleno. A responsabilidade socioambiental da empresa mostra a necessária colaboração do setor econômico privado com a promoção da sustentabilidade. Na mesma linha o princípio da defesa do meio ambiente 
estabelece que a livre iniciativa deve ser ponderada com a preservação ambiental e os valores sociais. Traduzido em um poder-dever do Estado, em que o Poder Público possui a incumbência de zelar pela preservação ambiental, e para alcançar tal objetivo poderá impor políticas públicas que limitam a liberdade de atuação do setor privado. Como não há como separar preservação ambiental e economia, uma vez que a base da cadeia produtiva, a geração de matérias primas, está na natureza, a jurisprudência do STF autoriza a mitigação da livre iniciativa visando a adequação do processo produtivo com as diretrizes de preservação ambiental e melhoria da qualidade de vida. Tal como postulado pela ADPF 101-DF, que versou sobre a importação de pneus remoldados, a nova ordem mundial impõe a adoção de medidas ambientais visando a proteção das futuras gerações, logo o desenvolvimento previsto pela CRFB é o que leva à dignidade humana em plenitude, e não à degradação. Seguindo a lógica do STF o princípio da defesa do meio ambiente fundamenta a possibilidade de adoção da responsabilidade socioambiental, uma vez que permite a mitigação da liberdade econômica em prol de valores maiores. O princípio da defesa do meio ambiente impõe ao Estado novas diretrizes na formulação das políticas econômicas, o que baliza a adoção da responsabilidade socioambiental da empresa. Na mesma linha o desenvolvimento sustentável prevê a preservação ambiental e a superação da miséria, idéia presente no Relatório Nosso Futuro Comum, na Agenda 21 e na Rio+20. Inclusive a Declaração da última conferência realizada ressalta a importância da economia verde, ou seja, a que resulta na melhoria de bem-estar da sociedade e da igualdade social, ao mesmo tempo que reduz de forma considerável os riscos e a escassez de recursos ambientais. Rio+20 ressaltou a a necessidade de diminuir a dependência excessivamente da energia proveniente dos combustíveis fósseis, e colocou a erradicação da pobreza como o maior desafio global atual, e um requisito essencial para o desenvolvimento sustentável, uma vez que é urgente libertar a humanidade da miséria e da fome. Logo a responsabilidade socioambiental da empresa concessionária de recursos florestais poderia ser utilizada como uma fonte de incentivos para as dez áreas essenciais para tornar a economia global mais verde. Por fim, mas não menos importante, o princípio do poluidor-pagador determina a internalização dos custos sociais externos que acompanham o processo produtivo, observando a vocação redistribuitiva do direito ambiental. Não seria possível que a sociedade suporte o ônus de recuperação da degradação causada por uma atividade cujo lucro será individualizado. Permitir tal prática equivaleria a autorizar o enriquecimento ilícito. O custo social da poluição deve ser suportado pelo empreendedor que aufere ganhos financeiros com a prática poluidora. A jurisprudência já aceitou tal possibilidade, através de institutos como a responsabilidade compartilhada na gestão de resíduos, e a Teoria do Risco Integral. Isto reforça a tese de que o Direito Ambiental vem aceitando, com base no princípio do poluidor-pagador, 
maiores imposições ao particular. Nesse sentido a adoção da responsabilidade socioambiental da empresa pode ser vista como uma das possíveis maneiras de correção das externalidades negativas.

É importante ressaltar que todas as fases da indústria do petróleo (os estudos de sísmica, a perfuração, a instalação de plataformas e a produção, as conseqüências dos acidentes e derramamentos bem como o refino e consumo final) geram expressivos impactos ambientais e, inclusive sociais. A prosperidade gerada pela atividade de $O \& G$ é freqüentemente localizada. A exploração off shore impede a pesca. Os antigos pescadores acabam sendo atraídos para outros postos de trabalho, gerados direta ou indiretamente, pela indústria petrolífera. A dependência ao setor do petróleo na região aumenta, além de obscurecer práticas sociais e culturais até então mantidas por gerações. O grande volume de migrantes aumenta as taxas de crescimento demográfico, mas os municípios do petróleo em regra apresentam um índice de desemprego superior à média nacional. O inchaço das cidades é seguido pela pressão por serviços públicos, tais como saúde, educação, qualificação profissional, saneamento básico, transporte e segurança. Mas a falta de emprego para a população que não possui qualificação específica para a atuação na indústria do petróleo contribui para o aumento da violência. Mais do que nunca é necessário substituir o modelo baseado em combustíveis fósseis por um pautado nas energias renováveis.

A biomassa para fins energéticos produzida por recursos madeireiros se destaca como uma solução viável, que pode gerar renda para o empresariado, diminuindo ou mesmo zerando a demanda energética do processo produtivo. Na mesma linha, os resíduos dos produtos madeireiros podem ser doados às populações tradicionais, solucionando a demanda energética das áreas com baixos índices de eletrificação.

Nesse contexto a adoção da responsabilidade socioambiental torna-se essencial. É possível identificar três linhas de atuação para a responsabilidade socia $\left.\right|^{96}$ que, não por acaso, estão ligadas às visões da economia sobre o meio ambiente. A primeira delas é a obrigação social, identificada com o pensamento de Milton Friedman. Postula que bastaria o empreendedor cumprir estritamente com suas obrigações legais para estar em dia com a sociedade: o beneficio seria sentido através da criação de empregos, salários justos e pagamento de impostos. A segunda seria a de Reação Social, ligada às preocupações com a imagem da corporação. As empresas seriam reativas: uma vez pressionadas pelos stakeholders reagiriam através da adoção de medidas éticas, e atendimento à legislação. A percepção é que se as empresas não se curvarem à sociedade e se continuarem a ignorar questões

${ }^{96} \mathrm{Cf}$. LOURENÇO, Alex Guimarães; SCHRODER, Débora de Souza. Vale investir em responsabilidade social empresarial? Stakeholders, ganhos e $\quad$ perdas. Disponível em <http://www.ethos.org.br/docs/comunidade_academica/premio_ethos_valor/trabalhos/300_Alex_e_Debora.do c> Acesso em: agosto de 2007. 
vitais para esta, poderão perder o jogo da competitividade. Por fim, a última linha é denominada Sensibilidade Social ou Pró-atividade Social. Baseia-se em comportamentos socialmente responsáveis, e em atuação preventiva. Os atos focariam além da mera preocupação em atender obrigações legais ou vencer a concorrência. A empresa é socialmente sensível, e procura solucionar problemas em uma atitude pró-ativa de responsabilidade socioambiental. Seus administradores são dotados de uma missão, tal como prevê a teoria da modernização ecológica. Justamente por ser motivada por diversos motivos, ou mesmo plenamente indesejada, estas ações carecem de uma regulação estatal, ainda que mínima. A crise de 2009 mostrou que a busca pela simples maximização dos lucros produz efeitos nefastos não só na economia, mas no meio ambiente e na vida da população. O papel do Estado regulador deve ser mais profundo, não se limitando apenas à economia e sim visando o alcance da sustentabilidade.

Um risco da adoção da função socioambiental da empresa seria, sem dúvidas, a possível substituição das Políticas Públicas pela atuação do empresariado que, ressalte-se, não possui legitimidade democrática. Corre-se o risco de frente a ineficiência e passividade do Estado o indivíduo achar mais simple pressionar grandes coorporações do que o governo. O capital privado deve exercer papel coadjuvante, e não de ator principal, mas não pode se esquivar de colaborar com a preservação ambiental e a superação de desigualades sociais. Logo a definição dos investimentos que a empresa privada fará deve ser definido pelo Poder Público. Tal como na compensação ambiental o Estado nortearia a aplicação dos recursos privados em ações de responsabilidade socioambiental. A intervenção do Ministério do Meio Ambiente e do Serviço Florestal Brasileiro seria necessaria para que os atos empresariais se alinhassem com os princípios ambientais.

Uma das críticas possíveis à imediata exigência de adoção da responsabilidade socioambiental, através da biomassa, nas concessões florestais seria sua falta de amparo normativo. Como a de Gestão de Florestas não é expressa neste sentido, tal imposição poderia ser ilegal e mesmo inconstitucional. A questão da obrigatoriedade de inclusão de ações de responsabilidade socioambiental é inédita. Mas é possível traçar um paralelo com outras regras para ajudar a dirimir esta provocação. Neste cenário imposição da adesão a responsabilidade socioambiental pelo Ministério do Meio Ambiente e pelo Serviço Florestal Brasileiro, se igualmente exigida dentro dos parâmetros do princípio da razoabilidade também não afastaria os players. Soma-se que a adoção de ações de responsabilidade socioambiental não só se coaduna com as mais modernas técnicas de administração de empresas, como também pode ser usado como estratégia de marketing positivo pelo setor privado. 
A adoção da responsabilidade socioambiental, e a imposição da biomassa gerada por resíduos florestais nos contratos de concessão florestal poderá garantir a sustentabilidade não só para as gerações futuras como possivelmente, para as atuais. Embora seja uma visão otimista esta hipótese é factível. E não custa esquecer que o Direito Ambiental demanda um mínimo de fé. Com crítica e sem ilusões, mas ainda com esperança.

\section{REFERÊNCIAS}

ALVAREZ, Allejandro Bugallo. Análise econômica do direito: contribuições e desmistificações. Direito Estado e Sociedade. Rio de Janeiro, n.29, p 49- 68, jul./dez. 2006.

AMUI, Sandoval. Petróleo e Gás Natural para Executivos. Rio de Janeiro: Interciência, 2010.

ANEFA. Biomassa Florestal Oportunidade e Valor. Lisboa: ANEFA, 2011. Disponível em $<$ http://www.anefa.pt>. Acesso em dezembro de 2014.

APEL, Karl-Otto. Discussion et responsabilité. Paris: Cerf, 1996. Estudos de Moral Moderna. Petrópolis: Vozes, 1994.

ASHLEY, Patrícia Almeida. Ética e responsabilidade social nos negócios. São Paulo: Saraiva, 2002. BARBOSA, Vanessa. Os 15 países com as maiores reservas de petróleo do mundo. Exame, São Paulo, 15 ago. 2012. Disponível em:< http://info.abril.com.br/noticias/tecnologias-verdes/os-15-paises-coma-maiores-reservas-de-petroleo-do-mundo.shtml>.Acesso em: out. de 2012.

Os 20 maiores consumidores de petróleo no mundo. Exame, São Paulo, 29 jun. 2013. Disponível em <http://exame.abril.com.br/meio-ambiente-e-energia/noticias/os-20-maiores-consumidores-depetroleo-no-mundo\#8>. Acesso em: jul. 2013.

BAUMFLEK, Imaly. O papel da OPEP no cenário internacional. In: RIBEIRO, Marilda Rosado de Sá (Org.). Estudos e Pareceres - Direito do Petróleo e Gás. Rio de Janeiro: Renovar, 2005.

BECK, Ulrich. Ecological Enlightenment: essays on the politics of the risk society. New York: Humanity Books, 1995.

La democracia y sus enemigos. Barcelona: Paidós, 2000.

La invención de lo político. Buenos Aires: Fondo de Cultura Económica

de Argentina, 1999.

BECK, Ulrich; BECK-GERNSHEIM, Elisabeth. La individualización: el individualismo institucionalizado y sus consecuencias sociales y políticas. Barcelona: Paidós, 2003.

La sociedad del riesgo global. Madrid: Siglo XXI de España, 2002.

La sociedad del riesgo: hacia una nueva modernidad. Barcelona: Paidós, 1998.

Liberdad o capitalismo: conversaciones con Johannes Willms. Barcelona: Paidós, 2002.

Presente y futuro del estado de bienestar: el debate europeo. Buenos Aires: Miño y Dávila, 2001.

Políticas ecológicas en la edad del riesgo: antídotos, la irresponsabilidad organizada. Barcelona:

El Roure, 1998. 2000.

Un Nuevo mundo feliz: la precariedad del trabajo en la era de la globalización. Barcelona: Paidós, 
World at Risk. Cambridge: Polity Press, 2010.

BECK, Ulrich; ZOLO, D. Sociedade Global do Risco. Tradução de Selvino J. Assmann. Entrevista disponível em: http://www.cfh.ufsc.br/ wfil/ulrich.htm. Acesso em: 03 jul. 2002.

BENJAMIN, Antônio H. O princípio do poluidor-pagador e a reparação do dano ambiental. Dano Ambiental, prevenção, reparação e repressão. São Paulo: RT, 1993. $52,1998$.

Responsabilidade civil pelo dano ambiental. Revista de Direito Ambiental, São Paulo, n. 09, p.5-

BIDERMAN, Rachel. et al. Guia de compras públicas sustentáveis: Uso do poder de compra do governo para a promoção do desenvolvimento sustentável. 2. ed. São Paulo: ICLEI, 2008.

BUTTEL, Frederick. Sociologia ambiental, qualidade ambiental e qualidade de vida in HERCULANO, Selene; PORTO, Marcelo Firpo de Souza; FREITAS, Carlos Machado (Org.). Qualidade de Vida e Riscos Ambientais. Rio de Janeiro: EdUFF, 2000.

BORGES, Roxana Cardoso Brasileiro. Direito Ambiental e teoria política no final do séc. XX. In:VARELLA, Marcelo Dias; BORGES, Roxana Cardoso Brasileiro (Orgs). O novo em Direito Ambiental. Belo Horizonte: Del Rey, 1998.

BROWN, Lester R. Eco-Economia: construindo uma economia para a terra. Salvador: UMA. 2003.

CALDERONI, Sabetai. Economia Ambiental. In: PHILIPPI JR., Arlindo; ROMÉRO, Marcelo de Andrade; BRUNA, Gilda Collet. Curso de Gestão Ambiental. São Paulo: Manole, 2004.

CANOTILHO, J. J. Gomes. Direito Constitucional e Teoria da Constituição. Coimbra: Almedina, 1998.

Proteç̧ão do Meio Ambiente e direito de propriedade: crítica de jurisprudência ambiental. Coimbra: Coimbra Editora, 1995.

CANOTILHO, J. J. Gomes. LEITE, José Rubens Morato. Direito Constitucional Ambiental Brasileiro. São Paulo: Saraiva, 2007.

CARVALHO, Cristiano de. Princípios e Conseqüências: a teoria da escolha racional como critério de ponderação - Introdução ao problema. Disponível em: http://www.viadesignlabs.com/lawandeconomics/Principios_e_Consequencias.pdf >. Acesso em: julho de 2008.

CHIAVENATO, Idalberto. Gestão de pessoas: o novo papel dos recursos humanos nas organizações. Rio de Janeiro: Ed. Campus, 1999.

CONFERÊNCIA DAS NAÇÕES UNIDAS SOBRE O MEIO AMBIENTE E O DESENVOLVIMENTO. Agenda 21 a a ed. Brasília: Senado Federal, Subsecretaria de Edições Técnicas, 2000.

CONFERÊNCIA DAS NAÇÕES UNIDAS SOBRE O MEIO AMBIENTE E O DESENVOLVIMENTO. Declaração Final da Conferência das Nações Unidas Sobre Desenvolvimento Sustentável (Rio+20). Disponível em <http://riomais20sc.ufsc.br/>, Acesso em junho de 2013.

COOTER, Robert y ULEN, Thomas. Derecho y Economía. Cidade do México: Editora Fondo de Cultura Económica., 1999. 
COSTA NETO, Nicolau Dino de Castro. Direito e Neoliberalismo. Revista de Informação Legislativa, $\mathrm{n}^{\circ}$ 160, p. 191-221, out./dez. 2003.

DERANI, Cristiane. Direito Ambiental Econômico. São Paulo: Max Limonad, 1997.

DRUKER, Peter F. Introdução à administração. São Paulo: Pioneira Thomson Learning, 2003.

EPE - EMPRESA DE PESQUISA ENERGÉTICA. Relatório Síntese Ano Base 2013. Disponível em https://ben.epe.gov.br/downloads/S\%C3\%ADntese\%20do\%20Relat\%C3\%B3rio\%20Final_2014_Web.p $d f>$, acesso em dezembro de 2014.

ESTY, Daniel; WINSTON, Andrew. Green to Gold: How Smart Companies Use Environmental Strategy to Innovate, Create Value, and Build Competitive Advantage. New Jersey: Jonh Wiley and Sons, 2009.

FAHIM, Mohammed; Al-Sahhaf, Taher. Introdução ao Refino de Petróleo. Rio de Janeiro: Campus, 2011.

FAVENNEC, Jean Pierre; BRET-ROUZAUT, Nadine. Petróleo e Gás Natural - Como Produzir e a Que Custo - 2a Ed. Rio de Janeiro: Synergia, 2011.

FERRAZ, Eduardo. A voz do visionário In Época Negócios. Disponível em http://epocanegocios.globo.com/Revista/Epocanegocios/0,,EDR76921-8374,00.html. Acesso em dezembro de 2012.

FRIEDMAN, Milton. Capitalismo e liberdade. São Paulo: Abril, 1984.

GIDDENS, Anthony. As conseqüências da modernidade. São Paulo: Universidade Estadual Paulista, 1991.

Modernidade e identidade. Rio de Janeiro: Jorge Zahar, 2002.

Mundo em descontrole: o que a globalização está fazendo de nós 2 a ed. Rio de Janeiro: Record, 2002.

GIDDENS, Anthony. PIERSON, Christopher. Conversas com Antonhy Giddens: o sentido da modernidade. Rio de Janeiro: FGV, 2000.

GIDDENS, Anthony, BECK, Ulrich; LASH, Scott. Modernização reflexiva: política, tradição e estética na ordem social moderna. São Paulo: Universidade Estadual Paulista, 1997.

GRAJEW, Oded. Instituto Ethos. Disponível em: <http://www.ethos.org.br>. Acesso em: agosto de 2007.

GRAU, Eros Roberto. A ordem econômica na Constituição de 1988 11a ed. São Paulo: Malheiros, 2006.

GRAUER, Andreas; KAWANO, Mauricy. Vantagens da Biomassa na Produção de Energia. Disponível em $<$ http://ambientes.ambientebrasil.com.br/energia/biomassa/vantagens_da_biomassa_na_producao_ de_energia.html>. Acesso em dezembro de 2014. 
GUERRA, Isabella Franco; LIMMER, Flávia C. Princípios constitucionais informadores do Direito Ambiental in PEIXINHO, Manoel Messias; GUERRA; Isabella Franco; e NASCIMENTO FILHO, Firly (orgs). Os princípios da Constituição de 1988. Rio de Janeiro: Lumen Juris, 2001, p. 581 / 593.

HAWKEN, Paul. Blessed Unrest. New York: Viking, 2007.

The Ecology of Commerce: a declaration of sustainability. New York: Haper Business, 1993.

HAWKEN, Paul ; LOVINS, Amory. Natural Capitalism: Creating the Next Industrial Revolution. New York: Back Bay Books, 2008.

JAHN, Frank; COOK, Mark; GRAHAM, Mark. Introdução À Exploração e Produção de Hidrocarbonetos. Rio de Janeiro: Campus, 2013.

KLEIN, Naomi. Sem Logo: a tirania das marcas em um planeta vendido 4a ed. Rio de Janeiro: Record, 2004.

The Shock Doctrine: the rise of disaster capitalism. New York: Metropolitan Books, 2007.

LEAL, Manoel Regis Lima Verde. O potencial de aproveitamento da energia de biomassa. In Inovação UNIEMP v.1 nº3. Campinas: UNIEMP, 2005.

LEITE, José Rubens Morato. Dano Ambiental: do individual ao coletivo extrapatrimonial. São Paulo: RT, 2000.

(Org.) Inovações em Direito Ambiental. Florianópolis: Fundação José Arthur Boiteux, 2000.

LEMOS, Patrícia Faga Iglecias. Resíduos Sólidos e Responsabilidade Civil Pós-Consumo 2a Ed. São Paulo: RT, 2012.

LIGTERINGEN, Ernest. Caminhando e conversando: stakeholders, juntos, a caminho de uma economia verde. In ALMEIDA, Fernando. Desenvolvimento Sustentável 2012-2050: visão, rumos e contradições. Rio de Janeiro: Campus, 2012

LUHMANN, Niklas. El concepto de riesgo. In BERIAIN, Josetxo. Las consecuencias perversas de la modernidad: modernidad, contingencia y riesgo. Tradução de Celso Sánchez Capdequí. Barcelona: Anthropos, 1996.

El futuro como riesgo. In BERIAIN, Josetxo. Las consecuencias perversas de la modernidad: modernidad, contingencia y riesgo. Tradução de Celso Sánchez Capdequí. Barcelona: Anthropos, 1996.

La contingencia como atributo de la sociedad moderna. In BERIAIN, Josetxo. Las consecuencias perversas de la modernidad: modernidad, contingencia y riesgo. Tradução de Celso Sánchez Capdequí. Barcelona: Anthropos, 1996.

Observations on modernity. Stanford, California: Stanford University Press, 1998.

MACHADO FILHO, Cláudio. Responsabilidade social corporativa e a criação de valor para as organizações: um estudo multicasos. São Paulo: USP, 2002. Tese. Faculdade de Economia, Administração e Contabilidade.

MACHADO, Paulo Affonso Leme. Direito Ambiental Brasileiro. 20ạ ed. São Paulo: Malheiros, 2014.

MILARÉ, Édis, Direito do Ambiente: doutrina, prática, jurisprudência, glossário 4ạ ed. São Paulo: RT, 2005. 
$\mathrm{MOL}$, Arthur. Ecological Modernization, industrial transformations and environmental reform In REDCLIFT, Michael; WOODGATE, G. (Orgs). The International Handbook of Environmental Sociology. London: Edward Elgar, 1997, p. 141-152.

A globalização e a mudança dos modelos de controle de poluição industrial: A teoria da modernização ecológica In HERCULANO, Selene; PORTO, Marcelo Firpo de Souza; FREITAS, Carlos Machado (Orgs.). Qualidade de Vida e Riscos Ambientais. Rio de Janeiro: EdUFF, 2000.

PARLAMENTO EUROPEU. Directiva 2001/77/CE do Parlamento Europeu e do Conselho, de 27 de Setembro de 2001, relativa à promoção da electricidade produzida a partir de fontes de energia renováveis no mercado interno da electricidade. Disponível em < http://eur-lex.europa.eu/legalcontent/PT/TXT/?uri=CELEX:32001L0077>. Acesso em dezembro de 2014.

PERELMAN, Chaïm. Ética e Direito. São Paulo: Martins Fontes, 1996.

PIMENTA, Ângela. Capitalismo: a solução para a Amazônia. In Exame, São Paulo, n. 923, 30.07.2008, p. 106/120.

O problema virou negócio. In Exame, São Paulo, n. 900, 29.08.2007, p.42-45.

POSNER, Richard A. Catastrophe: Risk and Response. New York: Oxford University Press, 2004.

Economic Analysis of the Law 4 ed. Boston: Little, Brown and Company, 1992.

PRIEUR, Michel. Droit de l'environnement. 5 ed. Paris: Dalloz, 2003.

PROGRAMA DAS NAÇÕES UNIDAS PARA O MEIO AMBIENTE. Rumo a uma economia verde: caminhos para o desenvolvimento sustentável e a erradicação da pobreza. PNUMA: 2011. Disponível em $<w w w . u n e p . o r g / g r e e n e c o n o m y>$. Acesso em maio de 2012.

REICH, Robert. Supercapitalismo: como o capitalismo tem transformado os negócios, a democracia e o cotidiano. Rio de Janeiro: Campus, 2008

Supercapitalism: the transformation of Business, Democracy, and Everyday Life. New York: Alfred A. Knopf, 2007.

RODRIGUES, Maria Cecília Prates. Ação Social das Empresas Privadas: como avaliar resultados? A metodologia EP2ASE. Rio de Janeiro: FGV, 2005.

SADELEER, Nicolas. Les principes du polluter-payer, de prévention et de précaution: essai sur la genése et la portée juridique de quelques principes du droit de l'environnement. Paris: Emile Bruylant, 1999.

SARLET, Ingo Wolfgang; FENSTERSEIFER, Tiago. Direito Constitucional Ambiental: Constituição, Direitos Fundamentais e Proteção do Ambiente 3 ed. São Paulo: RT, 2013.

SENGE, Peter; The Necessary Revolution: How individuals and organizations are working together to create a sustainable world. New York: Doubleday Publishing, 2008.

SILVA, Geraldo Eulálio do Nascimento e. Direito Ambiental Internacional: meio ambiente, desenvolvimento sustentável e os desafios da nova ordem mundial. 2 ed. rev. e atual. Rio de Janeiro: Thex 2002. 
SILVA, Juliana Marsico Correia da Silva; BOZELLI, Reinaldo Luiz; SANTOS, Laísa Freire; LOPES, Alexandre Ferreira. Impactos Ambientais da Exploração e Produção de Petróleo na Bacia de Campos, RJ. In IV Encontro Nacional da Anppas. Disponível em: $<$ http://www.ebah.com.br/content/ABAAAehvoAC/impactos-ambientais-exploracao-producaopetroleo-na-bacia-campos-rj>, Acesso em: setembro de 2011.

SOARES, Guido Fernando Silva. Direito internacional do meio ambiente: emergência, obrigações e responsabilidade. São Paulo: Atlas, 2001.

SROUR, Robert Henry. Ética empresarial: posturas responsáveis nos negócios, na política e nas relações pessoais. Rio de Janeiro: Campus, 2000.

STRUCHEL, Andréa; SERVILHA, Elson Roney. O direito, a lei e a gestão de florestas. In Revista de Direito Ambiental, v. 46, São Paulo, RT, abril-junho, 2007 p. 29-38.

SUNSTEIN, Cass. Risk and reason: safety, law, and the environment. Cambridge: Cambridge University Press, 2002.

THE WORLD COMMISSION ON ENVIRONMENT AND DEVELOPMENT. Our common future. New York: Oxford University, 1987.

THOMAS, José Eduardo. Fundamentos de Engenharia de Petróleo - 2a Ed. Rio de Janeiro: Interciência, 2004.

ULLER, Victor Cohen; BONFÁ, Márcio Henrique; SZKLO, Alexandre Salem. Fundamentos do Refino de Petróleo: Tecnologia e Economia. 3.ed. Rio de Janeiro: Interciência, 2012.

VAZ, Gil Nuno. Marketing institucional: o mercado de idéias e imagens. São Paulo: Pioneira, 1995.

VELÁZQUEZ, Silvia Maria Stortini; SANTOS, Sandra Maria Apolinario; MOREIRA, José Roberto; COELHO, Suani Texeira. A Geração de Energia Elétrica em Comunidades Isoladas da Amazônia a partir de Biomassa Sustentável: Projeto ENERMAD. Disponível em $<$ http://cenbio.iee.usp.br/download/publicacoes/xiiicbe_enermad.pdf>. Acesso em dezembro de 2014.

WAINER, Ann Helen. Legislação ambiental brasileira: evolução histórica do Direito Ambiental. In Revista de Direto Ambiental nº. São Paulo: RT.

WIECHETEK, Marcelo. Aproveitamento de Resíduos e Subprodutos Florestais, Alternativas Tecnológicas e Propostas de Políticas ao Uso de Resíduos florestais para Fins Energéticos. Brasília: Ministério do Meio Ambiente, 2009, pág. $09 . \quad$ Disponível em <http://www.mma.gov.br/estruturas/164/_publicacao/164_publicacao10012011033501.pdf>. Acesso em dezembro de 2014.

WORLDWATCH INSTITUTE. State of the world 2004: special focus the consumer society. New York: W. W. Norton \& Company, 2004.

ZYLBERSZTAJN, Décio, e SZTAJN, Rachel (Orgs). Direito e Economia: análise econômica do Direito e das Organizações. Rio de Janeiro: Elsevier, 2005. 
Trabalho enviado em 22 de março de 2015.

Aceito em 17 de maio de 2015. 